\title{
Ghrelin gene products, receptors, and GOAT enzyme: biological and pathophysiological insight
}

\author{
Manuel D Gahete, David Rincón-Fernández, Alicia Villa-Osaba, \\ Daniel Hormaechea-Agulla, Alejandro Ibáñez-Costa, Antonio J Martínez-Fuentes, \\ Francisco Gracia-Navarro, Justo P Castaño and Raúl M Luque
}

Department of Cell Biology, Physiology and Immunology, Campus Universitario de Rabanales, Edificio Severo Ochoa (C6), Planta 3, University of Córdoba, 14014-Córdoba; Instituto Maimónides de Investigación Biomédica de Córdoba (IMIBIC), University of Córdoba; Reina Sofia University Hospital, Córdoba; and CIBER Fisiopatología de la Obesidad y Nutrición (CIBERobn), Córdoba, Spain
Correspondence should be addressed to

R M Luque

Email

raul.luque@uco.es

\begin{abstract}
Ghrelin is a 28-amino acid acylated hormone, highly expressed in the stomach, which binds to its cognate receptor (GHSR1a) to regulate a plethora of relevant biological processes, including food intake, energy balance, hormonal secretions, learning, inflammation, etc. However, ghrelin is, in fact, the most notorious component of a complex, intricate regulatory system comprised of a growing number of alternative peptides (e.g. obestatin, unacylated ghrelin, and In1-ghrelin, etc.), known (GHSRs) and, necessarily unknown receptors, as well as modifying enzymes (e.g. ghrelin-O-acyl-transferase), which interact among them as well as with other regulatory systems in order to tightly modulate key (patho)-physiological processes. This multiplicity of functions and versatility of the ghrelin system arise from a dual, genetic and functional, complexity. Importantly, a growing body of evidence suggests that dysregulation in some of the components of the ghrelin system can lead to or influence the development and/or progression of highly concerning pathologies such as endocrine-related tumors, inflammatory/cardiovascular diseases, and neurodegeneration, wherein these altered components could be used as diagnostic, prognostic, or therapeutic targets. In this context, the aim of this review is to integrate and comprehensively analyze the multiple components and functions of the ghrelin system described to date in order to define and understand its biological and (patho)-physiological significance.
\end{abstract}

\author{
Key Words \\ - ghrelin \\ - ghrelin gene splice variants \\ - obestatin \\ - GHSR \\ - GOAT \\ - endocrine actions \\ - pathophysiology
}

\section{Introduction}

Ghrelin is an acylated hormone identified by reverse pharmacology as a 28-amino acid peptide highly expressed in rat stomach (Kojima et al. 1999). Specifically, the ghrelin receptor (GHSR) was first discovered by its ability to bind artificial compounds with growth hormone (GH)-releasing activity (hexarelin or GHRP6) (Howard et al. 1996) and, subsequently, ghrelin was identified as the endogenous ligand for this orphan receptor (Kojima et al. 1999). Intriguingly, evidence accumulated during the last 15 years has revealed that the ghrelin system is an extraordinarily sophisticated and multifunctional regulatory system composed of a number of related peptides and receptors present in a wide variety of tissues where they can exert endocrine, paracrine, and autocrine actions 
(Nishi et al. 2011). The multiplicity and versatility of the ghrelin system resides in a dual, genetic and functional complexity. From a genetic point of view, the originally identified ghrelin peptide is one of the components of a growing family of related peptides generated by processes of alternative splicing of the ghrelin gene or by posttranscriptional modifications (Seim et al. 2009). From a functional point of view, the ghrelin system has been found to be involved in the modulation of a multiplicity of (patho)-physiological functions such as hormonal secretions, memory and learning processes, food intake, body weight gain, insulin release, $\beta$-cell survival, adiposity, energy homeostasis, inflammatory processes, as well as in the development and progression of several types of cancers.

In this context, the aim of this review is to integrate and comprehensively analyze the multiple components and functions of the ghrelin system in order to define and understand its biological and (patho)-physiological significance. Particularly, certain endocrine and non-endocrine actions attributed to the ghrelin system are discussed in this review with the purpose of highlighting its dual, genetic and functional, complexity.

\section{Molecular biology of ghrelin system components}

\section{Ghrelin gene (GHRL)}

The initially identified ghrelin peptide results from proteolytic processing of a precursor peptide named preproghrelin. In humans, preproghrelin is encoded by a single-copy gene (GHRL) located on the short arm of chromosome 3 , which was originally thought to be composed of four coding exons (exons 1-4) (Sato et al. 2012). However, more recent studies have revealed the existence of a number of alternative upstream exons in the ghrelin gene (exon -1, exon 0 , and extended exon 1) that can act as alternative sites for transcription initiation, which considerably increases the complexity of this gene (Seim et al. 2009).

The originally identified preproghrelin mRNA transcript encodes a 117-amino acid long peptide in humans, whose sequence is highly conserved among the orthologous mammalian ghrelin prepropeptides (Seim et al. 2009, Sato et al. 2012). Specifically, human preproghrelin contains a signal peptide (23-amino acids) and a 94-amino acid segment called proghrelin, which undergoes a proteolytic processing that leads to the generation of the mature native ghrelin peptide, and also, to an additional
C-terminal peptide named C-ghrelin (Sato et al. 2012; Fig. 1). C-ghrelin peptide can subsequently undergo further proteolytic processes generating an alternative, functional peptide named obestatin, which was initially thought to be the antagonist hormone for ghrelin (Zhang et al. 2005; Fig. 1). Therefore, the originally identified native preproghrelin mRNA transcript yields, at least, two functional peptides, whose relevance during evolution is supported by the fact that the sequences of both hormones are highly conserved among vertebrates, and particularly, among mammalian genes (Kaiya et al. 2008).

In addition, native ghrelin peptide is subjected to a unique modification consisting of the acylation (addition of an octanoyl group) of the third serine residue (Ser3), which is well conserved among mammalian species (Nishi et al. 2011). According to its acylation status, the peptide can be termed unacylated ghrelin (UAG) or acylatedghrelin (AG), AG being the initially identified peptide (Kojima et al. 1999), which corresponds to the active peptide able to bind its canonical receptor, GHSR1a. The enzyme responsible for ghrelin acylation, known as ghrelin-O-acyl-transferase or GOAT, was discovered simultaneously by two laboratories (Gutierrez et al. 2008, Yang et al. 2008b; Figs 1 and 2). The acylation process by GOAT has been proposed to occur after signal peptide cleavage and before proteolytic processing (Garg 2007; Fig. 2); however, to date, it is not clear whether UAG is the product of an incomplete acylation of the nascent ghrelin peptide, or results from deacylation of mature AG (Nishi et al. 2011). Strikingly, although UAG represents over $90 \%$ of total blood ghrelin (Patterson et al. 2005), it does not bind the classic ghrelin receptor (GHSR1a), and its biological functions are not yet fully elucidated (Kojima et al. 1999).

Soon after the discovery of native ghrelin, several independent laboratories have identified a number of alternative ghrelin gene-derived peptides and mRNA splice variants (Seim et al. 2009, Gahete et al. 2011a, Nishi et al. 2011; Fig. 1). Some of those mRNA splicing variants generate peptides with small changes in their sequences compared with native ghrelin. This is the case of des-Gln14-ghrelin, which is identical to native ghrelin except for the deletion of one glutamine residue (Gln14). Unfortunately, the differences in function between this 27-amino acid peptide hormone and native ghrelin peptide are unknown (Sato et al. 2012). However, the ghrelin gene can also undergo additional processes of alternative splicing such as exon skipping or intron retention. Specifically, an event of exon 3 skipping has been documented (Yeh et al. 2005), which generates

Published by Bioscientifica Ltd. 


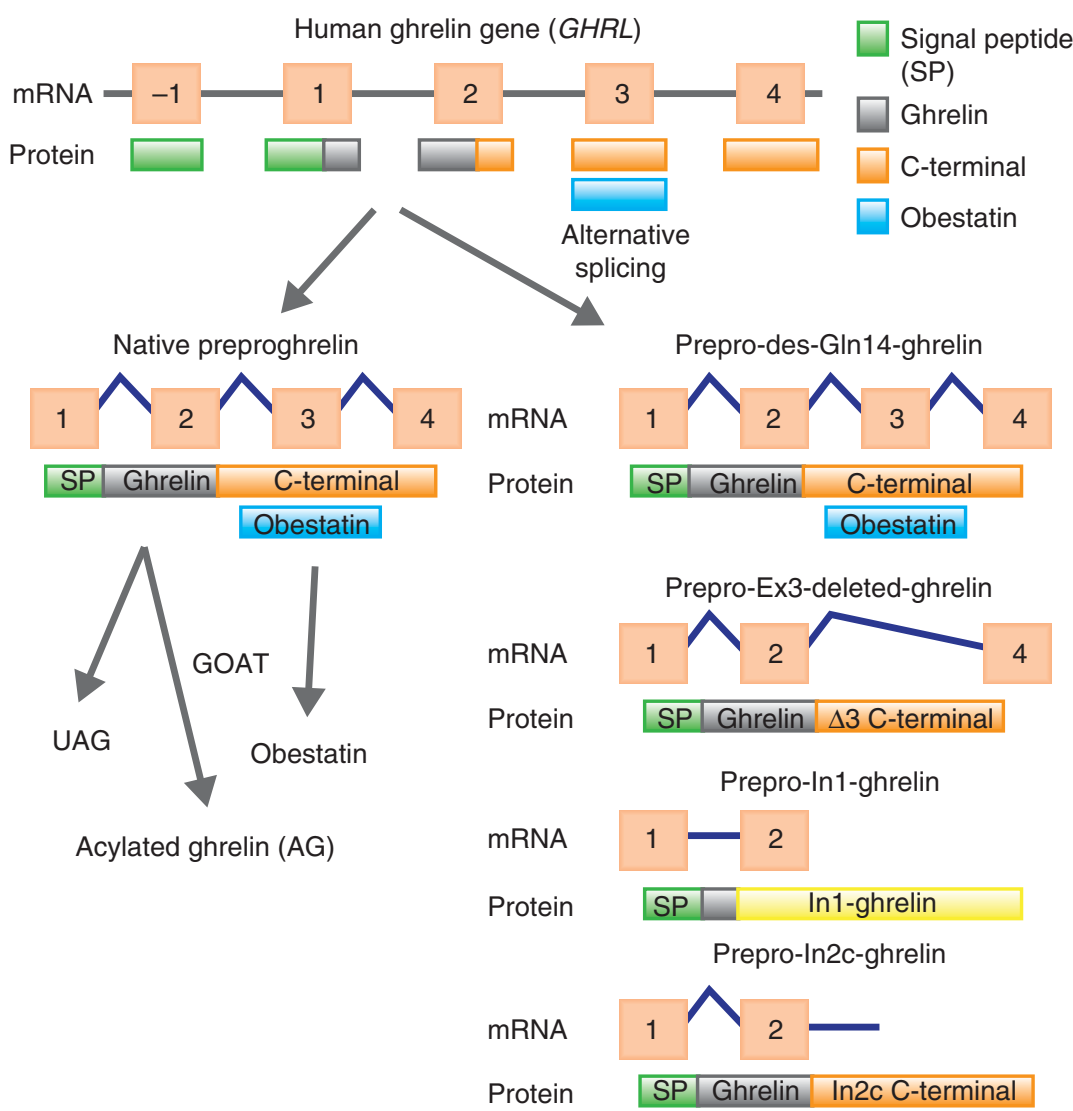

Figure 1

Overview of the human ghrelin gene structure and functionally relevant ghrelin gene derived variants (transcripts and putative peptides). Signal peptides are shown in green, ghrelin in grey, obestatin in blue and

a 91-amino acid peptide named the Ex3-deleted ghrelin that lacks the coding region for obestatin (Fig. 1). Although the precise functions of the Ex3-deleted ghrelin variant remain uncertain, its expression is increased in human prostate and breast cancers (Seim et al. 2009), suggesting a putative role in these pathologies. In addition, a novel ghrelin variant generated by retention of intron 1 (In1), and consequently named In1-ghrelin, has been recently identified. Similar to that found for Ex3-deleted ghrelin, In1-ghrelin variant is overexpressed in breast cancer samples (Gahete et al. 2011a). Interestingly, In1-ghrelin variant shares the signal peptide and initial portion of the peptide with native ghrelin, including the first 5 -amino acids, which is the minimum sequence required for ghrelin acylation by GOAT and for binding and activation of GHSR1a (Seim et al. 2009); however, the amino acid sequence of In1-ghrelin is subsequently altered by the retention of In1 (Fig. 1). Interestingly, similar intron retention processes have been identified in other mammalian species (Kineman et al. 2007,
C-peptides in orange. In the case of the In1-ghrelin variant, the sequence that is shared with ghrelin (exon 1; 12-amino acids) is shown in grey and the unique sequence generated by the retention of intron 1 is shown in yellow.

Gahete et al. 2011a). Specifically, the orthologous counterparts of the In1-ghrelin variant have also been found in mice (named In2-ghrelin (Kineman et al. 2007)) and in a nonhuman primate model (Gahete et al. 2011a), which suggest that this new variant might exert an important physiological role that is conserved among vertebrates. Of note, similar to that observed for native preproghrelin, In1-ghrelin prepropeptide also exhibits sites for putative protease action, suggesting that the full peptide could also be processed to yield mature peptides.

\section{Ghrelin receptor gene}

The GHSR is encoded by a conserved single-copy gene (GHSR) located on chromosome 3 in humans (Camiña 2006). Human GHSR gene is composed of two exons, whose alternative splicing can generate two mRNA species, named GHSR1a and GHSR1b. GHSR1a mRNA, which includes exons 1 and 2, encodes a 366-amino acid G protein-coupled receptor (GPCR) with seven

Published by Bioscientifica Ltd. 


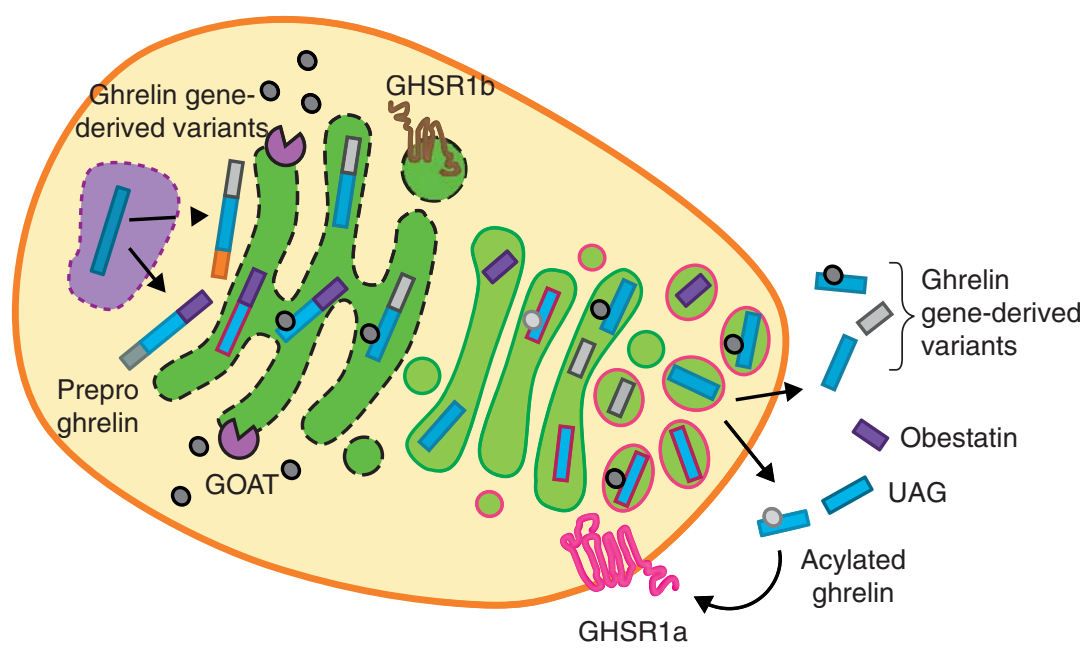

\section{Figure 2}

Overview of the post-transcriptional processing of native ghrelin and ghrelin gene derived peptides. During the post-translational modification of the native pre-pro-ghrelin, Ser3 can be acylated by GOAT. This modification of ghrelin is essential for binding to its only known receptor, GHSR1a, and to exert the majority of its biological functions. There is also a

transmembrane domains (TMDs). In contrast, GHSR1b mRNA results from retention of the intron located between exons 1 and 2, which generates a 289-amino acid GPCR isoform with only five TMDs, and having a dissimilar 24-amino acid sequence at the C-terminal region compared with the GHSR1a sequence. To date, the functional activity of truncated GHSR1b remains to be fully elucidated (Camiña 2006), while it is well-established that GHSR1a is the receptor responsible for transducing the signal of $A G$ and the family of synthetic $G H$ secretagogues (GHSs; Cong et al. 2010). In fact, the interaction of GHSR1a and AG is fundamentally determined by the high conformational flexibility introduced by ghrelin when it is modified with Ser3 acylation. Particularly, experimental acylation of ghrelin peptide at other Ser residues (Ser2, 6, and 18) has been found to reduce ghrelin functionality (Bednarek et al. 2000). Thus, the N-terminal region of Ser3 acyl-ghrelin might bind to the transmembrane cores of the GHSR1a, determining a particular orientation of the molecule where the C-terminal region of AG interacts with the exoloops and/or with the N-terminal segment of the receptor (Camiña 2006).

\section{Additional receptors for ghrelin gene-derived peptides}

The family of receptors that mediate the actions of ghrelin gene-derived peptides is yet to be fully identified. truncated orphan variant of the receptor, GHSR1b, with an unknown ligand and function. Additional ghrelin gene derived variants are likely to be similarly processed, generating a number of putative functional peptides, whose target receptors and biological actions are still to be elucidated

The putative presence of specific uncharacterized GHSR(s), different from GHSR1a, has been previously suggested in chondrocytes, human erythroleukemic HEL cells, and cardiomyocytes (Camiña 2006). In addition, the existence of a common uncharacterized receptor that mediates the biological effects shared by AG and UAG has also been postulated in breast cancer cell lines, cardiomyocytes, human prostatic tumors, and related cell lines (Cassoni et al. 2004). Also, the receptor(s) for obestatin is/are still undetermined. Although this peptide was initially reported to bind and activate the orphan G-protein-coupled receptor 39 (GPR39; Zhang et al. 2005), this notion is still a matter of debate and is losing support (Lauwers et al. 2006, Bassil et al. 2007, Chartrel et al. 2007); more recently, the glucagon-like peptide-1 receptor (GLP-1R) has been postulated as an alternative receptor for obestatin (Granata et al. 2008, 2012). Similarly, the receptor(s) that mediate(s) the biological actions of the recently identified splicing variants (In1-ghrelin, Ex3-deleted ghrelin, etc.) is/are still unknown.

\section{Ghrelin-O-acyl-transferase}

As mentioned above, ghrelin can be post-translationally modified at its Ser3 by GOAT (Gutierrez et al. 2008, Yang et al. 2008b), an enzyme that belongs to the superfamily of membrane bound $O$-acyltransferases (MBOATs; Chang \& Magee 2009), which is also named MBOAT4

Published by Bioscientifica Ltd. 
(Lim et al. 2011b). The human GOAT gene (MBOAT4) is located on chromosome $8 \mathrm{p} 12$ and its sequence is highly conserved across vertebrates (Muller et al. 2011). Indeed, amino acid sequences of human, mouse, and rat GOAT proteins show a $90 \%$ identity, and mouse and rat GOAT enzymes can faithfully octanoylate human ghrelin (Muller et al. 2011). Specifically, GOAT is a polytopic integral membrane protein that octanoylates Ser3 of proghrelin in the endoplasmic reticulum (ER) lumen after signal peptide cleavage (Taylor et al. 2013). GOAT enzyme is able to process a range of fatty acids, being the most likely acyl donors for the acyl-coAs and, for this reason, GOAT has been postulated to be a putative transporter of acyl-coA from the cytosol to the ER lumen (Yang et al. 2008b). GOAT mRNA is widely expressed in human tissues such as stomach, pancreas, skeletal muscle, heart, intestine, and bone (Lim et al. 2011a), a tissue expression pattern that partially resembles that exhibited by ghrelin (Lim et al. 2011a). Indeed, GOAT protein and mRNA transcripts exist in individual ghrelin-containing cells as is the case of gastric mucosal oxyntic cells (Sakata et al. 2009). Moreover, some studies have shown that GOAT mRNA expression levels do not exactly correlate with ghrelin expression levels, but they parallel the expression levels of the In1-ghrelin variant (Gahete et al. 2011a), suggesting the existence of putative additional targets for GOAT.

\section{Physiological role of the ghrelin system}

As previously indicated, the ghrelin system has been found to be involved in the modulation of a wide array of physiological functions. Specifically, the ghrelin system is commonly known by its ability to regulate not only endocrine actions (i.e., controlling pituitary hormone or pancreas secretions) but also some non-endocrine actions such as memory and learning processes (Gahete et al. 2011b), food intake (Nakazato et al. 2001), body weight gain, $\beta$-cell survival, adiposity, or energy homeostasis (Kirchner et al. 2012).

\section{Endocrine actions}

Pituitary gland The pituitary gland represents the main target for the endocrine actions of the ghrelin system. In fact, the GHSR was originally identified from swine, human, and rat pituitary glands (Howard et al. 1996, Guan et al. 1997, Korbonits et al. 1998). Accordingly, AG produced in the stomach was initially thought to regulate pituitary function in an endocrine manner. However, it has been demonstrated that native ghrelin is also expressed at the pituitary gland (Korbonits et al. 2001), suggesting the existence of a paracrine and/or autocrine regulation by locally produced ghrelin (Luque et al. 2006, Luque \& Kineman 2007). This idea is further reinforced by the fact that GOAT is also expressed in the hypothalamus and pituitary gland (Gahete et al. 2010a, Lim et al. 2011a). In addition, alternative ghrelin gene-derived variants, such as human In1-ghrelin or murine In2-ghrelin, have been also found to be present and regulated under different physiological conditions in the pituitary gland (Kineman et al. 2007, Gahete et al. 2011a), which further supports the idea of the existence of a complex regulation of pituitary function by the ghrelin system. In this sense, although AG was initially identified as a GH-secretagogue, it is nowadays well established that AG also regulates other pituitary secretions from both anterior and posterior pituitary gland.

Growth hormone As mentioned earlier, AG was initially identified by its ability to stimulate GH secretion in vitro in several species, including rats (Kojima et al. 1999, Tolle et al. 2001), mice (Luque, Córdoba-Chacón, IbáñezCosta, Gesmundo, Grande, Gracia-Navarro, TenaSempere, Ghigo, Gahete, Granata, Kineman and Castaño, 2013, unpublished observations), pigs (Glavaski-Joksimovic et al. 2003, Malagon et al. 2003), goldfish (Grey \& Chang 2011, 2013a,b), and baboons (Kineman \& Luque 2007), where it was demonstrated that $\mathrm{AG}$ is as potent as GHRH, the classical GH-releasing factor, in the stimulation of GH secretion (Kineman \& Luque 2007). In addition, the crucial role of native AG in the control of GH secretion has been extensively demonstrated in vivo, where AG potently stimulates GH release in humans (Takaya et al. 2000, Arvat et al. 2001, Hataya et al. 2001, Nagaya et al. 2001, Tassone et al. 2003, Garin et al. 2013) and rodents (Fernandez-Fernandez et al. 2005). Indeed, AG has been shown to be directly involved in the generation of the pulsatile GH secretion pattern (Nass et al. 2008), in that GH pulses and AG concentrations are highly correlated in a 1-hour interval during and before the pulse in healthy human subjects. AG seems to act through a variety of mechanisms and to establish a bidirectional, intricate crosstalk with other GH modulators in order to finely regulate GH-secretion. Specifically, it has been indicated that peripheral (stomach) AG could act via vagus nerve to increase GHRH and neuropeptide $Y$ (NPY) release, while centrally (hypothalamus) injected AG stimulates GHRH secretion and antagonizes somatostatin (SST) at the pituitary level (Wagner et al. 2009, Feng et al. 2011). Furthermore, SST inhibits not only GH but also

Published by Bioscientifica Ltd 
ghrelin release in healthy subjects, GH-deficient subjects, and acromegalic patients, in whom SST inhibited ghrelin plasma levels independently of GH status (Norrelund et al. 2002). The above-mentioned actions of AG seem to be mainly mediated by its cognate receptor GHSR1a in that GH expression is significantly decreased in GHSR-knockout (KO) mice compared with WT mice (Yang et al. 2008a).

In contrast to the well-established effect of native AG on the modulation of $\mathrm{GH}$ secretion, the role of other ghrelin gene-derived variants is still to be fully characterized. Specifically, to date, no effect of UAG has been found in the modulation of $\mathrm{GH}$ production/secretion (Kojima et al. 1999, Muccioli et al. 2002). In addition, the role exerted by obestatin on GH secretion is controversial. Thus, although some studies did not observe any effect of obestatin on GH secretion (Zhang et al. 2005, Nogueiras et al. 2007), others found a positive role for this peptide (Pazos et al. 2009). However, to the best of our knowledge, all studies performed to determine the role of obestatin on GH secretion have mainly used rat pituitaries or rat tumor cell lines and, therefore, the information gathered till now is limited and fragmentary. Interestingly, unpublished observations from our group indicate that obestatin inhibits GH expression and release in mouse and primate primary pituitary cell cultures, actions that are also observed in vivo in mice treated with obestatin (Luque, Córdoba-Chacón, Ibáñez-Costa, Gesmundo, Grande, Gracia-Navarro, Tena-Sempere, Ghigo, Gahete, Granata, Kineman and Castaño, 2013, unpublished observations).

Prolactin Native AG has also been found to stimulate prolactin (PRL) release from lactotrope cells (Arvat et al. 2001, Broglio et al. 2003, Tassone et al. 2003, Garin et al. 2013). This stimulatory effect has been shown to be independent of the well-known stimulator of PRL release, thyrotropin-releasing hormone (Messini et al. 2010b); however, it depends on the dopaminergic input. Specifically, AG-induced PRL release is not enhanced by a dopamine receptor blocker (Messini et al. 2011), but its effect is completely blocked by dopamine agonists (Messini et al. 2010a), suggesting a functional crosstalk between ghrelin and the dopamine systems. However, the molecular bases underlying this interaction are still to be elucidated. Interestingly, recent studies have suggested that the GHSR, GHSR1a, is also able to mediate AG-independent PRL stimulation in response to other ligands (Cordoba-Chacon et al. 2011). Specifically, cortistatin but not its related peptide, SST, is able to increase PRL secretion in mouse and baboon primary pituitary cell cultures, an effect that was completely blocked after a preincubation with a specific antagonist of the GHSR1a (Cordoba-Chacon et al. 2011). On the other hand, neither i.v. nor i.c.v. administration of obestatin has been shown to affect PRL secretion in rats (Yamamoto et al. 2007), while the effect of other ghrelin gene-derived variants has not been studied to date.

Proopiomelanocortin Proopiomelanocortin (POMC) is a precursor polypeptide with 241 -amino acids mainly synthesized in corticotroph cells of the anterior pituitary gland, whose cleavage processing leads to the production of adrenocorticotrophin hormone (ACTH). Native AG (Arvat et al. 2001, Broglio et al. 2003, Tassone et al. 2003, Vestergaard et al. 2007, Milosevic et al. 2013) or the synthetic GHSs (Korbonits et al. 1995, 1999, Bowers \& Granda-Ayala 1996, Arvat et al. 1997, Clark et al. 1997, Thomas et al. 1997) have been shown to stimulate ACTH secretion in several species, such as humans and rats. However, this effect could depend on the metabolic/ energy status, as AG-induced ACTH secretion has been shown to be impaired in obesity (Milosevic et al. 2013). Interestingly, recent studies have suggested that AG could be controlling ACTH release by acting at several levels, in that AG can act directly at the pituitary level by increasing free cytosolic calcium levels (Yamazaki et al. 2012) and also at the hypothalamic level by stimulating corticotrophinreleasing hormone (CRH) and arginine-vasopressin (AVP) production in rats (Wren et al. 2002). Although other ghrelin gene-derived products such as UAG and obestatin do not seem to exert any significant effect on the modulation of ACTH production and/or secretion (Yamamoto et al. 2007), the ghrelin gene plays a crucial role in the regulation of the stress response. Indeed, ACTH levels were significantly lower in ghrelin $\mathrm{KO}$ mice in response to stress, suggesting that some endogenous ghrelin genederived products, probably $A G$, modulate the response to acute stress, controlling the hypothalamic-pituitary-axis and diminishing anxious behavior under stress (Spencer et al. 2012).

Other anterior pituitary hormones The ghrelin system has also been shown to exert a crucial role in the regulation of other anterior pituitary hormones, through direct or indirect actions. Specifically, AG administration was shown to inhibit LH release in rats (Furuta et al. 2001, Fernandez-Fernandez et al. 2005), and FSH and LH in healthy men (Kluge et al. 2007, Lanfranco et al. 2008, Kluge et al. 2009) and women (Messini et al. 2010a, Kluge et al. 2012). On the other hand, the role of AG on TSH release is not well defined as some studies indicate a lack of direct effect on TSH release in humans (Takaya et al. 2000,

Published by Bioscientifica Ltd 
Hataya et al. 2001, Nagaya et al. 2001), while a recent study indicates that AG administration could induce a decrease in TSH release in healthy subjects (Kluge et al. 2010). Given that this study showed that AG was able to increase thyroxine, the authors speculate that the effect of AG on TSH might be mediated by a indirect action at the hypothalamic level through a thyroxine-dependent feedback (Kluge et al. 2010). Finally, glycoprotein hormones $\alpha$ chain (CGA) is the common subunit for FSH, LH, and TSH (and chorionic gonadotropin hormones) and is normally released as part of a heterodimer with these $\beta$ subunits. Interestingly, despite the lack of studies addressing the ability of the ghrelin system to modify CGA release, a recent work has demonstrated, by double immunostaining, that ghrelin is present in the majority of $\alpha$-subunit-producing cells (Rotondo et al. 2012), suggesting a possible functional role in its biogenesis.

Posterior pituitary hormones The ghrelin system has also been found to regulate the secretion of posterior pituitary hormones, including AVP and oxytocin (OT); however, this could be an indirect effect as studies in transgenic mice in which GHSR was labeled with GFP indicate that GHSR is not present in posterior pituitary (Reichenbach et al. 2012). Thus, native AG stimulates AVP release from rat posterior pituitary gland, probably via an indirect action mediated by NPY neurons (Ishizaki et al. 2002, Wren et al. 2002). Notably, AG-induced ACTH release has also been suggested to be mediated by the AG action on AVP secretion, because the AG-induced AVP rise precedes the increase in ACTH and cortisol levels in response to AG injection in healthy men (Coiro et al. 2005). On the other hand, the relationship between the OT and ghrelin systems has not been fully elucidated. While it has been demonstrated that OT could not inhibit the stimulatory effect of AG on GH, PRL, and ACTH release in healthy subjects (Coiro et al. 2011), it might influence the effect of AG on NPY secretion (Coiro et al. 2008), which suggests the existence of an intricate relationship between both neuropeptide systems.

Gastrointestinal tract Ghrelin is mainly produced in the stomach by a specific population of endocrine cells located in the gastric mucosa, the so-called A-like cells (Kojima et al. 1999), but it has also been detected in other gastrointestinal tract (GIT) regions such as the small intestine (Ghelardoni et al. 2006). Moreover, obestatin is also expressed in the mucosa of the GIT. Indeed, the subcellular localization of obestatin and ghrelin has been shown to be identical, within the same secretory vesicles, suggesting that obestatin and ghrelin are possibly costored in the same cells in the GIT (Gronberg et al. 2008). Similarly, recent studies have also demonstrated that GOAT enzyme expression is highly enriched within gastric ghrelin-producing cells (Sakata et al. 2009). Interestingly, other ghrelin gene-derived variants, such as In1-ghrelin, have also been found to be expressed in the GIT (Gahete et al. 2011a), although the specific cells where they are produced are yet to be determined. The fact that GHSR expression has also been detected in stomach, as well as in small and large intestine (Gnanapavan et al. 2002), suggests that ghrelin may play a role in the regulation of other GIT hormones. Unfortunately, studies reported hitherto have generated conflicting results (Lee et al. 2002, Dornonville de la Cour et al. 2004, de la Cour et al. 2007). Although initial studies suggested that i.v. administration of ghrelin could increase gastrin secretion in rat stomach (Lee et al. 2002), later studies did not find any effect of AG or UAG in the secretion of gastrin, SST, or histamine in the same species (Dornonville de la Cour et al. 2004). Interestingly, ghrelin secretion is also regulated by other GIT hormones (de la Cour et al. 2007). In particular, adrenaline, noradrenaline, endothelin, and secretin seem to stimulate, while SST and GRP seem to inhibit ghrelin secretion at stomach level (de la Cour et al. 2007), which suggests the existence of a complex feedback regulatory system among GIT hormone systems.

Pancreas The endocrine pancreas includes a population of cells (epsilon cells ( $\varepsilon$-cells)) that are specialized in the production and secretion of ghrelin (Wierup et al. 2002). However, ghrelin production has also been shown in other pancreatic cell types such as $\alpha$ - and $\beta$-cells (Date et al. 2002, Dezaki et al. 2004, Granata et al. 2007), suggesting a paracrine/autocrine action of the ghrelin system in the pancreas. Indeed, the endocrine pancreas is a key target tissue for the actions of ghrelin. Specifically, AG plays an important role in the regulation of glucose homeostasis by inhibiting insulin release in mice, rats, and humans (Broglio et al. 2001, Egido et al. 2002, Reimer et al. 2003, Granata et al. 2007). AG also modulates the production/secretion of glucagon from the pancreas (Chuang et al. 2011) and, indeed, it has been demonstrated that GHSR colocalizes with glucagon and insulin in rat pancreatic islets, which further indicates that the ghrelin system plays an important role in pancreatic $\alpha$ - and $\beta$-cells (Kageyama et al. 2005). In addition, AG has been shown to be able to modulate insulin actions, as it can induce peripheral insulin resistance (Damjanovic et al. 2006, Vestergaard et al. 2008) without affecting hepatic

Published by Bioscientifica Ltd. 
insulin sensitivity (Vestergaard et al. 2013). Therefore, due to this crucial role of AG in the regulation of pancreas and insulin physiology, it has been suggested that GHSR blockers and/or GOAT inhibitors might be used as putative antidiabetic drugs in the future (Gualillo et al. 2008, Barnett et al. 2010).

In addition, obestatin expression has also been shown in the pancreas (Chanoine et al. 2006, Zhao et al. 2008). However, the role that obestatin may play in the regulation of endocrine pancreas secretions is poorly understood. In fact, obestatin seems to exert dosedependent and species-specific effects on glucose-induced insulin secretion (Egido et al. 2009). At high glucose levels, obestatin inhibits insulin secretion from murine pancreatic islets, while, at low glucose concentrations, it increases insulin secretion from human $\beta$ cells (Granata et al. 2008, Qader et al. 2008). Moreover, obestatin probably plays a relevant role in the promotion of human islet cell survival and $\beta$-cell functioning (Granata et al. 2008). Recent observations have also suggested that other ghrelin gene-derived molecules could be present in the endocrine pancreas, as in the case of the In1-ghrelin variant (Chanclon et al. 2013), where it might play a functional role, which merits further investigation.

Adrenal gland The ghrelin system is known to be involved in the control of the hypothalamus-pituitaryadrenal axis activity in humans and other mammals (Giordano et al. 2006). However, the precise role of the ghrelin system in the physiology of the adrenal gland has not been fully elucidated. Specifically, it has been shown that some ghrelin gene-derived hormones, GOAT, and GHSRs are expressed in the cortex and/or the medulla of human and rat adrenal glands (Barreiro et al. 2002, Andreis et al. 2003, Tortorella et al. 2003, Raghay et al. 2008, Rucinski et al. 2009, Lim et al. 2011a). Indeed, the GHSR seems to be more abundant in the adrenal zona glomerulosa, the cambium layer involved in the maintenance of adrenal cortex growth (Tortorella et al. 2003). Interestingly, ghrelin and GHSR expression seems to be reduced in the human adrenal cortex with aging (Carraro et al. 2004, 2006).

Initial reports discarded a direct action of the ghrelin system on adrenal secretion, in that AG and/or obestatin did not significantly affect either basal or agonist (ACTH and angiotensin-II)-stimulated corticosterone secretion from adrenal cells in vitro (Barreiro et al. 2002, Andreis et al. 2003, Tortorella et al. 2003, Rucinski et al. 2009). However, a more recent study has shown that prolonged in vitro exposure to $A G$, but not to obestatin, could stimulate corticosterone secretion in rats (Rucinski et al. 2009). A more consistent explanation seems to be that AG, via GHSR1a, could be involved in the autocrine-paracrine control of human adrenal growth, as AG can enhance the proliferation rate of cultured zona glomerulosa cells, without affecting the apoptotic deletion rate (Andreis et al. 2003). Moreover, AG treatment is able to increase the absolute whole adrenal gland weight and volume in rats in vivo (Milosevic et al. 2010). Altogether, these data suggest that the ghrelin system could exert a direct role in the autocrine-paracrine regulation of human adrenal growth (Tortorella et al. 2003), while it might exert an indirect role, via ACTH release, on glucocorticoid secretion.

\section{Nonendocrine actions}

Regulation of energy balance, appetite, and body temperature AG promotes a positive energy balance by increasing food intake and reducing energy expenditure, therefore leading to an increase in body weight and adiposity (Tschop et al. 2000). Indeed, one of the central roles of the ghrelin system is the regulation of feeding and energy homeostasis (Wren et al. 2000, Nakazato et al. 2001). AG is known as the 'hunger hormone' and several studies indicate that circulating ghrelin levels rise in fasting and between meals, while AG levels decrease during the post-prandial state (Cummings et al. 2001). Moreover, AG has been found to stimulate energy intake in experimental animals (Wren et al. 2000, Jonsson 2013) and healthy men (Wren et al. 2001). Specifically, this hormone exerts its orexigenic effects acting at the level of a brain area known to be crucial in the regulation of feeding: the hypothalamus. Here it activates neurons of the arcuate nucleus, particularly, NPY- and agouti-related peptide (AgRP)-producing neurons (Nazakato et al. 2001), probably through the modulation of the mTORC1/S6K1 pathway (Stevanovic et al. 2013). AG reaches the hypothalamus through three different pathways: first, through the general circulation, by crossing the blood-brain barrier; secondly, through the vagal afferent nerves; and thirdly, it can be synthesized in the hypothalamus, where it may directly exert paracrine effects (Lim et al. 2011b). However, the regulation of food intake by AG seems to be tightly dependent on the metabolic status. Recent studies have demonstrated that exogenous AG administration can induce hyperphagia in free-feeding rats but not in animals under negative metabolic conditions, such as fasting or in chronically food-restricted animals (Alen et al. 2013). AG has also been shown to increase energy intake in situations of impaired appetite or cachexia, a common problem in

Published by Bioscientifica Ltd. 
cancer patients (Molfino et al. 2013). In striking contrast, UAG has been shown to suppress food intake (Asakawa et al. 2005). In that both AG and UAG derive from the same precursor, the inverse effects of these two peptides suggest that the stomach, the main source of circulating AG and $U A G$, might be involved, somehow, in the sensing and regulation of energy balance. In addition, although obestatin was initially postulated as the ghrelin antagonistic hormone, nowadays its effect on food intake remains strongly controversial. Specifically, obestatin has been shown to suppress food intake and energy balance in some rodent studies (Zizzari et al. 2007, Hassouna et al. 2012, Gargantini et al. 2013), while no effect has been reported by different studies in rats and mice (Gourcerol \& Tache 2007, Kobelt et al. 2008).

Despite the well-established role of the ghrelin system in the regulation of feeding behavior and energy expenditure, its implication in thermoregulation, an additional process in the regulation of energy balance, is still to be fully elucidated. Initial studies suggested a biphasic action of AG on thermogenesis, in that low doses of AG could reduce body temperature (Lawrence et al. 2002), while high doses could increase it (Jaszberenyi et al. 2006), probably through a hypothalamic action (Tokizawa et al. 2012). This idea is supported by the fact that ghrelin gene $\mathrm{KO}$ mice cannot control body temperature under extreme thermic conditions (Szentirmai et al. 2009), and because areas of the hypothalamus located in the vicinity of cold-sensitive neurons exhibit ghrelin-binding sites (Wiedmer et al. 2011). However, these data are in contrast with other studies showing that, under extreme thermic conditions, both GHSR-KO (Szentirmai et al. 2009) and GOAT-KO mice (Heppner et al. 2013) can control core body temperature, and with those showing that $A G$ administration does not alter body temperature in mice, rats, and humans (Wiedmer et al. 2011). In this scenario, the actions of alternative ghrelin gene-derived peptides could shed some light on this controversy, in that, for example, obestatin has been shown to attenuate the hypothermic response of ghrelin gene $\mathrm{KO}$ mice (Szentirmai et al. 2009), thereby suggesting a complex regulation of body temperature by the ghrelin system.

Gastric motility and acid secretion $A G$ is a potent accelerator of gastric emptying and a stimulator of GI motility in humans (Tack et al. 2006), rats (Trudel et al. 2002, Xu et al. 2013), and mice (Masuda et al. 2000, Fujino et al. 2003, Ariga et al. 2007, Zheng et al. 2009); while this effect was not observed in dogs (Ohno et al. 2010). Indeed, gastric emptying is delayed in GHSR-deficient mice
(Yang et al. 2013) and, interestingly, these mice exhibited a reduction in the number of nerve cells in the gastric muscle, where GHSR is predominantly expressed (Yang et al. 2013). AG induces motor activity in the GIT via a dual, central and peripheral, mechanism (Korbonits et al. 2004). The central mechanism is mediated through NPYneurons of the arcuate nucleus, the vagus nerve, and/or the lateral septum (Gong et al. 2013); while peripheral effects include the induction of the GI phase III contractions (Fujitsuka et al. 2012). In addition, AG has also been found to be able to stimulate, in a dose-dependent manner, the acid secretion from rat stomach (Masuda et al. 2000), probably through a nitric oxide-dependent pathway (Bilgin et al. 2008).

Similar to that observed for food intake regulation, UAG has been shown to exhibit an opposite role to that exerted by AG, in that UAG suppresses gastric emptying in the antrum (Asakawa et al. 2005). This seems to be an indirect effect mediated via the hypothalamus by the activation of anorexigenic cocaine- and amphetamineregulated transcripts as well as urocortin gene expression (Asakawa et al. 2005). Similarly, obestatin has also been described as an inhibitor of motor activity in the gastroduodenal region in the fed state, but not in the fasted state, an effect that seems to be an indirect action in which CRH type 1 and type 2 receptors might be involved (Ataka et al. 2008). However, obestatin was unable to antagonize AG-induced stimulation of gastroduodenal motility (Ataka et al. 2008).

Cognitive processes The ghrelin system has been shown to be involved in the regulation of many brain functions such as the modulation of cognitive processes, acting at the hypothalamus and other brain areas. Specifically, i.c.v. application of AG stimulates memory retention (Carlini et al. 2002), in a dose-dependent manner (Stoyanova et al. 2013) and independent of the brain area injected (hippocampus, amygdala, or dorsal raphe) (Carlini et al. 2004), through processes that could include the promotion of neurogenesis (Li et al. 2013) and synaptic plasticity (Abizaid et al. 2006). Indeed, AG but not UAG can enhance synaptic plasticity through both presynaptic (enhancing presynaptic excitatory inputs) and postsynaptic (elevating excitability of postsynaptic neurons) mechanisms (Chen et al. 2011) in the hippocampus, where the AG-induced synaptic changes closely parallel the enhanced hippocampus-dependent spatial learning and memory. Consistently, ghrelin KO mice exhibit impaired performance in behavioral memory testing, which is reversed by AG administration

Published by Bioscientifica Ltd. 
(Diano et al. 2006). The fact that intra-hippocampal AG administration improved long-term memory but did not modify short-term memory (Carlini et al. 2010) suggests that AG may modulate memory acquisition/consolidation but not the retrieval. Unfortunately, the role of other ghrelin gene-derived variants in the regulation of cognitive functions is still uncertain. It has been shown that UAG can induce proliferation of neuronal precursor cells in the rat fetal spinal cord (Sato et al. 2006); however, the role of obestatin and ghrelin splice variants remains unexplored.

Neuroprotection Frago et al. (2002) provided the first evidence for the neuroprotective effects of ghrelin analogs in several brain areas of adult rats. Further studies have demonstrated the potential of ghrelin to stimulate neural survival in diverse experimental models of ischemia, traumatic brain injury, spinal cord injury, amyotrophic lateral sclerosis, epilepsy, Alzheimer's disease (AD), and Parkinson's disease (PD) (Liu et al. 2006, Chung et al. 2007, Dos Santos et al. 2013, Kenny et al. 2013). Of note, the actions of ghrelin in neuroprotection seem to be specifically mediated by the inhibition of proapoptotic molecules associated with mitochondrial pathways and by activating endogenous protective molecules (Miao et al. 2007). Interestingly, ghrelin acts by inhibiting apoptotic pathways regardless of its acylation (Chung et al. 2008); however, while AG acts through GHSR1a, UAG would bind to the CD36 scavenger receptor to exert these actions (Bulgarelli et al. 2009).

Cardiovascular actions The ghrelin system has also been implicated in the regulation of cardiovascular physiology by acting at different levels of the cardiovascular system (vascular, endothelial, and/or cardiac). Specifically, AG increases cardiac output, decreases blood pressure, increases cardiac contractility and vasodilation, inhibits apoptosis in endothelial cells and cardiomyocytes, and decreases peripheral resistance (Tesauro et al. 2010). These actions seem to be mediated by its cognate receptor as the expression of GHSR1a has been found in human cardiomyocytes, myocardium, and aorta (Gnanapavan et al. 2002). Similarly, the presence of the truncated GHSR1b variant has also been found in human myocardium; however, its (patho)physiological function, if any, is still unknown (Zhang et al. 2010). It is also noteworthy that cardiomyocytes and endothelial cells are able to produce ghrelin itself, suggesting that this peptide could exert paracrine/autocrine actions to regulate cardiac function (Iglesias et al. 2004, Kleinz et al. 2006).
Interestingly, locally produced UAG has been shown to exert different actions from those observed for $A G$ in terms of the regulation of glucose and fatty acid uptake from cardiomyocytes (Lear et al. 2010), which suggests a complex relationship between the ghrelin and cardiovascular systems.

Immune system and inflammation The ghrelin system has also been reported to be widely distributed among immune- and inflammatory-related tissues and cells. In particular, ghrelin is expressed in a variety of immune cells and tissues such as T-lymphocytes, B-lymphocytes, neutrophils, spleen, or lymph nodes (Hattori et al. 2001). The presence of GHSRs in immune cells has also been reported (Hattori et al. 2001). Surprisingly, human GHSR1a seems to have a very restricted expression, mainly circumscribed to the spleen, thymocytes, and some subpopulations of immune cells, while the truncated variant GHSR1b has been found to have a wider distribution, including spleen, lymph nodes, thymocytes, lymphocytes, and other peripheral blood mononuclear cells (Hattori et al. 2001).

From a physiological point of view, AG has been shown to be able to influence thymopoiesis, as infusion of AG increases the number of thymocytes and thymus size in mice (Dixit et al. 2007), suggesting a relevant role of the ghrelin system in the development and maturation of the thymus. Moreover, this is supported by the fact that the accelerated age-dependent involution of the thymus observed in ghrelin KO mice can be partially reversed by AG administration (Dixit et al. 2007). Importantly, these results have led to the idea that the decreased immune response observed in the elderly could be improved by enhancing AG signaling. Furthermore, AG can regulate the physiology of the immune system by regulating the production and secretion of a number of proinflammatory cytokines such as TNF $\alpha$, IL6, IL1 $\beta$ in human and animal models (Hosomi et al. 2008), which is further supported by the fact that serum or plasma ghrelin levels are increased in different types of inflammatory diseases including ulcerative colitis, Crohn's disease, ankylosing spondylitis, pancreatitis, colitis, and rheumatoid arthritis (Baatar et al. 2011). The presence and the role of other ghrelin genederived variants on the immune system remain unknown.

\section{Pathological implications of ghrelin system}

Inasmuch as the ghrelin system plays a relevant role in the modulation of a plethora of physiological processes, changes in this regulatory system have also been

Published by Bioscientifica Ltd. 
associated with the development and/or progression of a number of pathological conditions. Particularly, AG can increase cell proliferation in several healthy and cancer tissues, as well as regulate invasiveness, migration, metastasis, and apoptosis in various cell types (Jeffery et al. 2002, Pettersson et al. 2002, Duxbury et al. 2003, De Vriese et al. 2005, Maccarinelli et al. 2005, Marjchrzak et al. 2012, Yu et al. 2013).

\section{Endocrine-related tumors}

Pituitary adenomas Several studies have demonstrated that ghrelin, as well as GHSR1a and GHSR1b, are differentially expressed in pituitary adenomas (Korbonits et al. 1998, 2001, Kim et al. 2001). Specifically, it has been reported that ghrelin expression levels are similar between gonadotropinomas or prolactinomas and normal pituitaries (NPs); however, nonfunctioning pituitary adenomas (NFPA) and somatotropinomas seem to exhibit higher expression levels of ghrelin, while corticotropinomas express lower ghrelin mRNA levels than NPs. On the other hand, while GHSR1a and GHSR1b are poorly expressed in gonadotropinomas, the expression levels of both receptors have been found to be higher in somatotropinomas, corticotropinomas, and prolactinomas compared with NPs but did not differ between NFPA and NPs.

Acromegaly Acromegaly is a syndrome mostly caused by GH hypersecretion from tumoral pituitary somatotrope cells, and subsequent increase in IGF1 production by the liver. The main consequences of chronic exposure to GH and IGF1 are skeletal, tissue, and organ growth, including acral changes, gigantism, arthritis, heart disorders, diabetes, insulin resistance, hypogonadism, etc. (Melmed 2009). As AG is one of the main primary stimulators of the production and secretion of $\mathrm{GH}$, it has been suggested that changes in the ghrelin system might play a role in the development and/or progression of GH-producing adenomas. However, there is controversial data on this topic as circulating levels of ghrelin have been found to be reduced (Cappiello et al. 2002, Freda et al. 2003), elevated (Jaskula et al. 2009), or not changed (Barkan et al. 2003, Jarkovska et al. 2006, Isidro et al. 2007, Jaskula et al. 2009) in acromegalic patients compared with healthy subjects. Interestingly, normalization in circulating ghrelin levels has been observed after adenoma surgery in some (Freda et al. 2003) but not all studies (Kawamata et al. 2007). All these studies have pointed out that factors other than GH, IGFI, and insulin could be differentially influencing the circulating ghrelin levels in acromegalic patients; as in the case of the lipid profile (Jaskula et al. 2009).

AG enhances GH release in GH-producing adenomas in vitro (Rubinfeld et al. 2004), and has been shown to be locally produced in somatotropinomas (Kim et al. 2001, Korbonits et al. 2001); however, no significant correlation between circulating GH levels before surgery and ghrelin mRNA expression in the tumors has been observed (Korbonits et al. 2001). Surprisingly, a previous study showed that ghrelin mRNA levels in somatotropinomas were negatively correlated with tumor size and, indeed, high-grade tumors had lower levels of ghrelin mRNA than low-grade adenomas (Kim et al. 2001). On the other hand, both GHSR1a and GHSR1b have been found to be highly expressed in somatotropinomas compared with NPs (Barlier et al. 1999, Korbonits et al. 2001, Rubinfeld et al. 2004), which together with the previous data mentioned in this section, might suggest the existence of an autocrine/paracrine role of the ghrelin system in GHproducing adenomas. Moreover, studies in a rat pituitary somatotrope cell line indicate that both AG and UAG can stimulate cell proliferation (Nanzer et al. 2004). In spite of all these studies, the data reported to date which focused on the role that ghrelin plays in GH-producing adenomas are limited and inconclusive; this, together with the fact that the effects of other ghrelin gene-derived variants on GH-producing tumors has not yet been explored, suggest that further work should be conducted to elucidate the precise role of the ghrelin system in the development and progression of GH-producing adenomas.

Prolactinomas Prolactinomas are caused by the presence of PRL-producing (lactotrope) tumoral cells in the pituitary gland, which produces clinical symptoms such as weight gain, infertility, galactorrhea, gonadal dysfunction, headache, hypopituitarism, and visual field defects (Colao 2009). Although the presence of ghrelin and its receptor has been confirmed in prolactinomas (Kim et al. 2001, Korbonits et al. 2001, Rotondo et al. 2011), limited studies have been carried out to elucidate the direct pathological role of the ghrelin system in these tumors. Specifically, a previous study revealed that AG treatment elicited PRL release in prolactinomas and GHPRL mixed adenoma cell cultures (Rubinfeld et al. 2004), suggesting an involvement of the ghrelin system in the development and progression of prolactinomas. However, to the best of our knowledge, the role of other ghrelin gene-derived peptides, such as UAG or obestatin, on prolactinomas has not been explored so far.

Published by Bioscientifica Ltc. 
Cushing's disease Cushing's disease is the result of chronic exposure to cortisol due to an ACTH-producing pituitary adenoma and is characterized by central obesity, diabetes mellitus, dyslipidemia, hypertension, hirsutism, muscle weakness, and emotional disturbances (Feelders \& Hofland 2013). The expression of some ghrelin genederived components and GHSRs has been detected in ACTH-secreting adenomas (Kim et al. 2001, Korbonits et al. 2001, Martinez-Fuentes et al. 2006, Pecori Giraldi et al. 2007, Rotondo et al. 2011). Indeed, ghrelin, GHSR1a and GHSR1b are highly expressed in ACTH-secreting adenomas, where ghrelin and ACTH have been shown to be costored in the same secretory granules (Martinez-Fuentes et al. 2006), suggesting a putative autocrine/paracrine role of the ghrelin system in ACTH-secreting adenomas. Interestingly, it has been indicated that the well-known ACTH releasing effect of AG observed in tumoral corticotrope cells (Pecori Giraldi et al. 2007) might be mediated via increased free cytosolic calcium levels (Martinez-Fuentes et al. 2006). Finally, a recent study has suggested that AG administration may be used in the diagnosis of Cushing's disease with adrenal enlargement, in that these patients do not respond correctly to a desmopressin test, while they clearly respond to $A G$, suggesting that $A G$ is able to stimulate ACTH and cortisol release in all forms of Cushing's disease (Miljic et al. 2010).

NFPA, gonadotropinomas, and thyrotropinomas Approximately $40-50 \%$ of pituitary adenomas are gonadotrope-derived tumors (Chaidarun \& Klibanski 2002), most of them being classified as NFPA and nullcell adenomas (Colao et al. 2008), which are characterized by the lack of hormone release by the tumor, provoking a variety of symptoms including headache, visual defects, hypogonadism, and hypopituitarism. A small proportion of these gonadotrope-derived tumors secrete FSH and/or LH and are generally named gonadotropinomas (Chaidarun \& Klibanski 2002), which may cause ovarian hyperstimulation, testicular enlargement, and precocious puberty. There is also a rare kind of pituitary adenomas that secrete TSH, named thyrotropinomas, characterized not only by the typical pituitary adenoma symptoms (headache, visual defects, and hypopituitarism) but also by thyroid dysfunction (Beck-Peccoz et al. 2009). Surprisingly, although the presence of ghrelin system components has been detected in these pituitary adenomas (Kim et al. 2001, Korbonits et al. 2001, Rotondo et al. 2011), no functional studies have been implemented to date and, therefore, the role of the ghrelin system in the pathology of NFPA, gonadotropinomas, and thyrotropinomas is still to be elucidated.

Neuroendocrine tumors Neuroendocrine tumors (NETs) comprise a group of extraordinary heterogeneous neoplasias originated in the diffuse neuroendocrine system of the GIT, where neuroendocrine GIT and pancreas tumors are included. Expression of some components of the ghrelin system has been detected in normal and tumoral tissues of the GIT. Indeed, ghrelin, obestatin, GOAT, and GHSRs are expressed in gastric (Papotti et al. 2001, Rindi et al. 2002, Volante et al. 2002), intestinal (Inhoff et al. 2008), and/or pancreatic carcinoids (Volante et al. 2002, Ekeblad et al. 2007), although their expression levels vary depending on the tissues and the detection method used (Papotti et al. 2001, Rindi et al. 2002, Volante et al. 2002, Inhoff et al. 2008). However, it is not clear whether the expression profile of the ghrelin system is altered in NETs compared with control tissues. For example, obestatin seems to be similarly expressed in normal and carcinogenic tissues, but its secretion seems to be reduced in oncological conditions due to posttranslational modifications (Volante et al. 2002). In addition, most of the studies have shown that plasma ghrelin concentrations lie within the normal range in NETs patients, and ghrelin elevation has been only found in two cases of ghrelinomas. Unfortunately, to the best of our knowledge, the functional role of the ghrelin system components in the development and/or progression of NETs has not been explored to date.

Adrenal tumors The presence and the role of the ghrelin system in adrenal tumors have been largely underexplored. Specifically, some studies have reported variable levels of ghrelin mRNA and/or protein in the majority of several types of human and rat adrenal tumors such as pheochromocytomas, cortisol-secretin adenomas, aldosterone-secreting adenomas, and adrenocortical carcinomas (Barzon et al. 2005, Raghay et al. 2008, Ueberberg et al. 2008). In contrast, expression of the cognate receptor GHSR1a has been undetectable in most of the adrenal tumors analyzed to date. However, its presence has been found in a few pheochromocytomas, cortisol-secretin adenomas, and adrenocortical carcinoma samples (Barzon et al. 2005, Ueberberg et al. 2008). The presence of other components of the ghrelin system has not been explored and the functional role of the ghrelin system in these tumors is unknown. Nevertheless, the fact that ghrelin expression has been found in various types of adrenal tumors might indicate that this

Published by Bioscientifica Ltd. 
regulatory system has some unknown pathophysiological functions, which remain to be investigated.

Breast Breast cancer is the most common malignancy in women worldwide and remains a significant health issue in industrialized countries (Siegel et al. 2013). Breast cancer seems to be initiated by defined genomic alterations, many of which could be used as therapeutic targets or biomarkers. In line with this, the presence of the majority of the ghrelin system components (ghrelin, obestatin, ghrelin splicing variants, GOAT, and GHSRs) has been extensively proven in normal mammary gland, breast tumors, and breast cancer cell lines (Chopin et al. 2012). In particular, native ghrelin and obestatin expression has been found in a high proportion of breast cancer tissues with different grades (Gronberg et al. 2012), although its expression does not seem to be increased in breast cancer compared with healthy tissues (Gahete et al. 2011a). Indeed, expression of ghrelin and obestatin have been associated with a positive outcome in invasive breast tumor as patients with ghrelin-expressing tumors exhibited 2.5-3 times lower risk for recurrence of breast cancer than those lacking ghrelin expression (Gronberg et al. 2012).

However, several ghrelin gene polymorphisms have been associated with an increase in breast cancer risk (Dossus et al. 2008), suggesting that a dysbalance in normal expression of the ghrelin system in mammary gland tissue could be involved in breast tumor pathogenesis. This is indeed supported by the observation that several ghrelin gene-derived splicing variants are overexpressed in breast cancer tissue (Jeffery et al. 2005, Gahete et al. 2010b). In particular, expression of the In1-ghrelin variant is eightfold higher in a series of 40 sporadic invasive ductal breast carcinomas compared with normal breast tissues (Gahete et al. 2011a), while Ex3-deleted ghrelin variant is overexpressed in the MDA-MB-435 metastatic breast cancer cell line relative to the benign MCF-10A breast epithelial cell line (Jeffery et al. 2005). In addition, GOAT expression has recently been described in breast cancer cell lines, and its expression seems to be elevated in breast cancer tissues compared with normal breast samples (Gahete et al. 2011a). Interestingly, GHSR1a is also present in both normal and tumoral breast samples (Jeffery et al. 2005, Gahete et al. 2011a), while the GHSR1b receptor seems to be selectively expressed in breast carcinoma, where its abundance shows a strong correlation with In1-ghrelin expression levels (Gahete et al. 2011a). Indeed, expression of the cognate GHSR GHSR1a could even be reduced in breast cancer samples compared with normal mammary gland (Gahete et al. 2011a). In line with this, it has been suggested that the hypermethylation of the GHSR promoter region could be the underlying cause of this phenomenon, as hypermethylation is a frequent hallmark observed in primary breast tumor (Ordway et al. 2007) and its levels are negatively associated with GHSR1a expression (Botla et al. 2012).

Despite the obvious association between the presence and changes of ghrelin gene products and breast cancer, limited and conflicting data are available on the functional role that the ghrelin system plays in the regulation of patho-physiologically relevant processes in breast cancer development and progression. Specifically, Cassoni et al. showed a decrease in proliferation after ghrelin administration in breast cancer cell lines (Cassoni et al. 2004), while other study observed an opposite effect (Jeffery et al. 2005). A more consistent explanation seems to be the effect of the In1-ghrelin variant, which, in addition to being overexpressed in breast cancer samples, has been shown to promote basal proliferation in the MDA-MB-231 breast cancer cell line (Gahete et al. 2011a).

Prostate Prostate cancer is the most commonly diagnosed malignancy and one of the leading causes of cancer-related deaths in the male population (Siegel et al. 2013). Remarkably, prostate cancer development and progression is highly influenced by the endocrine milieu. In this sense, plasma AG, but not UAG or obestatin, has been found to be elevated in prostate cancer patients (Malendowicz et al. 2009). In addition, the majority of the ghrelin system components are locally produced in the prostate tissue. Particularly, the expression of ghrelin has been detected in normal prostate, human benign hyperplasia, and prostate carcinoma (Cassoni et al. 2004) as well as in prostate cancer cell lines (Jeffery et al. 2002, Cassoni et al. 2004, Yeh et al. 2005). Indeed, locally produced ghrelin seems to be secreted from prostate tissue as it is detected in the medium collected from the PC3 cancer cell line (Jeffery et al. 2005). In vivo, ghrelin expression seems to be mainly restricted to the glandular epithelial cell cytoplasm with lower staining intensity in the normal glandular tissue compared with malignant prostate epithelium (Yeh et al. 2005). Similarly, GOAT expression has also been detected in normal and tumoral prostate tissues and its expression can be modulated by AG, but not by UAG, in normal and tumoral prostate derived cell lines (Seim et al. 2013a). In contrast, the presence and abundance of GHSRs (GHSR1a and GHSR1b) in prostate cells are still to be fully defined. Some studies have shown

Published by Bioscientifica Ltd 
that GHSR1a is present in a normal prostate cDNA library (Jeffery et al. 2002), and absent in carcinomas, while GHSR1b is present in $50 \%$ of prostate hyperplasias (Cassoni et al. 2004). Likewise, their presence in prostatederived cell lines is still controversial, in that some studies showed the expression of GHSRs in the majority of cell lines analyzed (ALVA 41, PC3, LNCaP, and DU145) (Jeffery et al. 2002), while other studies only reported their presence in a reduced number of prostate cancer cell lines (Cassoni et al. 2004). These differences and discrepancies between studies might be explained by the use of different techniques (PCR, ICC, western blot). However, it is clear that further studies are required to unequivocally determine whether GHSRs are present in prostate cells.

Unfortunately, the role of the ghrelin system in prostate cancer cell biology is unclear, probably due to the reduced number of studies performed, and to the conflicting results generated in the reports published to date. In particular, some studies support the idea that AG increases prostate cell line proliferation (Jeffery et al. 2005), which could be mediated through the activation of key signaling pathways such as MAPK/ERK and/or PI3K/AKT/mTOR (Yeh et al. 2005), and protects against actinomycin D-induced apoptosis (Yeh et al. 2005). Conversely, other studies have reported an antiproliferative and proapoptotic effect of AG in prostatic cancer cells (Diaz-Lezama et al. 2010, Lawnicka et al. 2012). As these studies employed different concentrations of AG, it has been postulated that the physiological levels of AG could act as a positive factor for prostate cells growth, while supra-physiological levels could exert an inhibitory effect. Similarly, the role of ghrelin gene splicing variants is still to be fully elucidated in prostate cells. The Ex3-deleted preproghrelin isoform has been detected in the medium collected from the PC3 cancer cell line; while the In1-ghrelin variant and the recently identified In2c-ghrelin variant (Fig. 1) have also been shown to be expressed in prostate cancer cell lines (Seim et al. 2013b); however, the pathophysiological role of these variants is still unknown (Jeffery et al. 2005, Seim et al. 2013b). Therefore, further studies are granted to gain insights into the exact role that the ghrelin system exerts in the modulation of prostate tissue biology.

\section{Inflammation/cardiovascular diseases}

Ghrelin in inflammation and aging Several pieces of evidence suggest a central role of the ghrelin system in the control of the inflammatory process and in the evolution of aging. Indeed, plasmatic levels of ghrelin and tissue levels of some of the components of the ghrelin system (ghrelin and its receptors) are regulated during states of acute and chronic inflammation, stress, and/or aging (Baatar et al. 2011). In addition, increases in circulating levels of ghrelin have been found in several inflammatory disease states including ulcerative colitis, Crohn's disease, pancreatitis, ankylosing spondylitis, sepsis, colitis, and rheumatoid arthritis (Osawa 2008, Hattori 2009), where its expression levels have also been directly correlated with the severity of the disease and inversely correlated with the expression of proinflammatory cytokines such as IL6, IL1 $\beta$, and TNF $\alpha$ (Taub 2008). Therefore, these data suggest an important role for the ghrelin system in the regulation of various proinflammatory disease states in humans and in animal models (Dixit $\&$ Taub 2005, Mafra et al. 2011). Indeed, the use of ghrelin as a therapeutic treatment has been examined in several studies using rodent models of sepsis and endotoxemia, chronic disease, and/or injury (Hattori 2009). Specifically, the use of AG was reported to suppress the expression and/or production of cytokines such as TNF $\alpha$, IL6, IL1 $\beta$, and CRP in these models, which was associated with an increase in the survival rate (Taub 2008, Taub et al. 2010).

Finally, the idea that the ghrelin system may influence tissue homeostasis and control the local inflammatory state, together with the fact that thymic and splenic expression of the ghrelin system is significantly diminished with advancing age (Taub et al. 2010), has led to the conclusion that AG administration to older people could serve as a potential therapy to reduce the increased levels of IL6, IL17, and other inflammatory mediators associated with aging and frailty (Taub et al. 2010). However, the role of the ghrelin system in the modulation of the inflammatory process is not fully characterized and cautions should be taken in the interpretation of these results.

Ghrelin in cardiovascular diseases As mentioned above, the ghrelin system is present in both vascular and cardiac tissues and seems to improve the physiological performance of the cardiovascular system, which has led to the hypothesis that the ghrelin system could exert a protective effect in cardiovascular diseases. Indeed, evidence accumulated during the last decade demonstrated that ghrelin could exert a potential therapeutic benefit in several cardiovascular-related dysfunctions such as myocardial infarction, heart failure, cardiopulmonary bypass, ischemia, atherosclerosis, and/or chronic hypoxia. Specifically, chronic or acute AG treatment in mice has been shown to improve myocardial function and recovery after myocardial infarction, which is often associated with subsequent heart failure (Nagaya \& Kangawa 2003).

Published by Bioscientifica Ltd. 
In fact, ghrelin has been suggested to have a potential therapeutic benefit in heart failure patients, in whom administration of ghrelin significantly improves left ventricular ejection fraction, increases peak workload and peak oxygen consumption during exercise (Kishimoto et al. 2012), improves cardiac function, and decreases systemic vascular resistance (Nagaya \& Kangawa 2003). Similarly, AG treatment reduces inflammatory response, apoptosis and oxidative stress, and preserves the cardiac pumping function in a rat model of cardiopulmonary bypass through GHSR1a and Akt signaling (Cao et al. 2013). In addition, AG exerts a protective effect against ischemia/reperfusion injury (Chang et al. 2004), probably through a direct effect on the heart (Kishimoto et al. 2012) and also exerts a vasodilatory effect in the vasculature (Isgaard \& Granata 2011, Lacerda-Miranda et al. 2012), which may be of potential importance for the development of atherosclerosis. Finally, a therapeutic benefit of ghrelin in the treatment of pulmonary hypertension has also been suggested, particularly in subjects prone to chronic hypoxia, a state that elevates pulmonary arterial pressure and increases the wall thickness of peripheral pulmonary arteries, because ghrelin treatment can attenuate, in rats, the hypoxia-induced development of pulmonary arterial hypertension and pulmonary vascular remodeling (Kishimoto et al. 2012).

The pathophysiological implications of the ghrelin system in cardiovascular diseases is further supported by epidemiological studies that indicate that single nucleotide polymorphisms (SNPs) in the ghrelin gene, which influence ghrelin levels in the circulation, could be associated with an altered hypertension risk (Liu et al. 2011). In addition, SNPs in the GHSR gene could also be markers for cardiac diseases, in that allele frequencies in the regulatory region of GHSR differ significantly between individuals with or without left ventricular hypertrophy (Liu et al. 2011). Unfortunately, to the best of our knowledge, the role of other components of the ghrelin system in cardiovascular diseases has not been explored to date.

\section{Neurodegeneration}

Recent data demonstrating that ghrelin is involved in neuroprotection, together with the wide distribution of GHSRs in many brain areas, have reinforced the idea that changes in the ghrelin system could be implicated in the development and/or progression of some neurodegenerative diseases such as $\mathrm{AD}$ and $\mathrm{PD}$.

Alzheimer's disease $\mathrm{AD}$ is the most prevalent agerelated neurodegenerative disease and is markedly influenced by metabolic and inflammatory status. $\mathrm{AD}$ is characterized by a marked impairment in memory and learning processes, two cognitive functions in which the ghrelin system has been shown to play a relevant role. Indeed, in 2002, it was reported that plasma ghrelin levels were lower in older subjects than in young subjects, providing the first evidence for an age-related decline in plasma ghrelin concentration (Rigamonti et al. 2002). Although later studies showed that ghrelin levels did not vary in the cerebrospinal fluid of $\mathrm{AD}$ patients when compared with age-matched controls (Proto et al. 2006), more recent studies provide strong evidence to suggest an association between dysregulations in the ghrelin system and AD incidence. Particularly, our group analyzed the mRNA expression levels of the ghrelin system in three different regions of the temporal gyrus of control and $\mathrm{AD}$ human brains, showing for the first time that AD patients had a reduction in local brain ghrelin production compared with age-matched controls (Gahete et al. 2010b). Moreover, In1-ghrelin and the GOAT enzyme were also present in the temporal lobe and were downregulated in $\mathrm{AD}$ (Gahete et al. 2010b). This study also revealed that the ratio between GHSR1a and GHSR1b receptors was altered in $\mathrm{AD}$ patients, suggesting that these changes in the ghrelin system could be involved in the severity of the disease. The fact that recent data indicate that SNPs of the ghrelin gene are associated with the age of $\mathrm{AD}$ onset (Shibata et al. 2011), together with the observation that male patients with $\mathrm{AD}$ have a disruption in the normal compensatory modulation of ghrelin secretion (Theodoropoulou et al. 2012), strongly reinforce the idea that the ghrelin system should be considered as a potential therapeutic target in the treatment of AD-related comorbidities.

Parkinson's disease $\mathrm{PD}$ is the second most common neurodegenerative disorder. The disease affects the motor system and results from the progressive degeneration of dopamine neurons in the pars compacta of the substantia nigra (SNpc; Bisaglia et al. 2013). The limitations of the current dopamine-replacement therapy have led to extensive investigation of novel nondopaminergic drugs that may provide treatment for PD symptoms (Bisaglia et al. 2013). Despite the limitations in the generation of animal and cellular models of PD that accurately resemble the processes known to occur during PD-associated cell death, 1-methyl-4-phenyl-1,2,3,6-tetrahydropyridine (MPTP)-treated animal models have emerged as a widely used approach for studying PD pathobiology (Langston \& Ballard 1983). Due to the positive role of the ghrelin

Published by Bioscientifica Ltd. 
system in the promotion of neural survival and in the dopaminergic-system function, an increasing number of studies have investigated, over the last years, the effects of ghrelin in different animal models. These studies have suggested that ghrelin might exert an effect in the treatment of PD. Specifically, it has been demonstrated that ghrelin can inhibit the MPTP-induced dopaminergic neuronal loss and dopamine depletion in mice (Jiang et al. 2008), probably through a dual neuronal-microglial action, in that ghrelin can protect the normal dopamine function by activating UCP2-dependent mitochondrial mechanisms (Andrews et al. 2009) and can act as a survival factor for dopaminergic neurons by functioning as a microglia-deactivating factor (Moon et al. 2009). The fact that GHSRs are expressed in the SNpc (Andrews et al. 2009) has reinforced the potential value of the ghrelin system as a novel, palliative, and neuroprotective target in neurodegenerative diseases such as PD. However, further studies are required in order to fully elucidate the implications and putative therapeutic use of the ghrelin system in PD-associated neuronal impairment.

\section{Concluding remarks and future directions}

Over 14 years have passed since the discovery of ghrelin (Kojima et al. 1999). Since that time, an emerging body of evidence has grown to support the notion that several components of the ghrelin system are expressed in a wide variety of tissues, where they play crucial roles by regulating multiple biological functions. However, this evidence also revealed that the ghrelin system is far more complex than it was originally envisioned. The complexity of this system lies on the existence of multiple ghrelin genederived variants, receptors, and interrelated enzymes (e.g., GOAT), which have been found to be expressed throughout the body, and also on the fact that the ghrelin system may play a crucial role in the regulation of a variety of pathophysiological processes (e.g., development and progression of endocrine-related tumors, inflammatory/ cardiovascular diseases and neurodegeneration). The data summarized in this review highlights the conception that ghrelin is one of the components of a complex, intricate regulatory system composed of a growing number of alternative peptides, regulatory enzymes, known and unknown receptors, which can interact with them as well as with other regulatory systems in order to tightly modulate relevant biological and pathophysiological processes. However, several relevant questions regarding the composition and function of the ghrelin system in different tissues and cells types still remain unknown.
Therefore, additional efforts from the scientific community will be necessary to better understand the composition, functions, and relationships among the different components of the ghrelin system under normal (biological/ physiological) conditions, as well as in pathological states, by continuing to employ, refine, and develop new and more representative in vitro and in vivo experimental approaches targeting the ghrelin system.

\section{Declaration of interest}

The authors declare that there is no conflict of interest that could be perceived as prejudicing the impartiality of this review.

\section{Funding}

This work has been funded by grants from Junta de Andalucía (BIO-0139, CTS-5051 and PI-0369-2012), Ministerio de Economía y Competitividad (BFU2008-01136, BFU2010-19300 and FPU12/01086), FEDER, CIBERobn, Merck Serono Foundation and Instituto de Salud Carlos III ('Sara Borrell' program CD11/00276). CIBER is an initiative of Instituto de Salud Carlos III, Ministerio de Sanidad, Servicios Sociales e Igualdad, Spain.

\section{References}

Abizaid A, Liu ZW, Andrews ZB, Shanabrough M, Borok E, Elsworth JD, Roth RH, Sleeman MW, Picciotto MR, Tschop MH et al. 2006 Ghrelin modulates the activity and synaptic input organization of midbrain dopamine neurons while promoting appetite. Journal of Clinical Investigation 116 3229-3239. (doi:10.1172/JCI29867)

Alen F, Crespo I, Ramírez-López MT, Jagerovic N, Goya P, de Fonseca FR, de Heras RIG \& Orio L 2013 Ghrelin-induced orexigenic effect in rats depends on the metabolic status and is counteracted by peripheral CB1 receptor antagonism. PLoS ONE $\mathbf{8}$ e60918. (doi:10.1371/journal.pone. 0060918)

Andreis PG, Malendowicz LK, Trejter M, Neri G, Spinazzi R, Rossi GP \& Nussdorfer GG 2003 Ghrelin and growth hormone secretagogue receptor are expressed in the rat adrenal cortex: evidence that ghrelin stimulates the growth, but not the secretory activity of adrenal cells. FEBS Letters 536 173-179. (doi:10.1016/S0014-5793(03)00051-6)

Andrews ZB, Erion D, Beiler R, Liu ZW, Abizaid A, Zigman J, Elsworth JD, Savitt JM, DiMarchi R, Tschoep M et al. 2009 Ghrelin promotes and protects nigrostriatal dopamine function via a UCP2-dependent mitochondrial mechanism. Journal of Neuroscience 29 14057-14065. (doi:10.1523/JNEUROSCI.3890-09.2009)

Ariga H, Tsukamoto K, Chen C, Mantyh C, Pappas TN \& Takahashi T 2007 Endogenous acyl ghrelin is involved in mediating spontaneous phase III-like contractions of the rat stomach. Neurogastroenterology and Motility 19 675-680. (doi:10.1111/j.1365-2982.2007.00945.x)

Arvat E, Ramunni J, Bellone J, Di Vito L, Baffoni C, Broglio F, Deghenghi R, Bartolotta E \& Ghigo E 1997 The GH, prolactin, ACTH and cortisol responses to hexarelin, a synthetic hexapeptide, undergo different age-related variations. European Journal of Endocrinology 137 635-642. (doi:10.1530/eje.0.1370635)

Arvat E, Maccario M, Di Vito L, Broglio F, Benso A, Gottero C, Papotti M, Muccioli G, Dieguez C, Casanueva FF et al. 2001 Endocrine activities of ghrelin, a natural growth hormone secretagogue (GHS), in humans: comparison and interactions with hexarelin, a nonnatural peptidyl GHS, and GH-releasing hormone. Journal of Clinical Endocrinology and Metabolism 86 1169-1174. (doi:10.1210/jc.86.3.1169) http://joe.endocrinology-journals.org DOI: 10.1530/JOE-13-0391
C 2014 Society for Endocrinology Printed in Great Britain 
Asakawa A, Inui A, Fujimiya M, Sakamaki R, Shinfuku N, Ueta Y, Meguid MM \& Kasuga M 2005 Stomach regulates energy balance via acylated ghrelin and desacyl ghrelin. Gut 54 18-24. (doi:10.1136/gut.2004. 038737)

Ataka K, Inui A, Asakawa A, Kato I \& Fujimiya M 2008 Obestatin inhibits motor activity in the antrum and duodenum in the fed state of conscious rats. American Journal of Physiology. Gastrointestinal and Liver Physiology 294 G1210-G1218. (doi:10.1152/ajpgi.00549.2007)

Baatar D, Patel K \& Taub DD 2011 The effects of ghrelin on inflammation and the immune system. Molecular and Cellular Endocrinology $\mathbf{3 4 0}$ 44-58. (doi:10.1016/j.mce.2011.04.019)

Barkan AL, Dimaraki EV, Jessup SK, Symons KV, Ermolenko M \& Jaffe CA 2003 Ghrelin secretion in humans is sexually dimorphic, suppressed by somatostatin, and not affected by the ambient growth hormone levels. Journal of Clinical Endocrinology and Metabolism 88 2180-2184. (doi:10.1210/jc.2002-021169)

Barlier A, Zamora AJ, Grino M, Gunz G, Pellegrini-Bouiller I, MorangeRamos I, Figarella-Branger D, Dufour H, Jaquet P \& Enjalbert A 1999 Expression of functional growth hormone secretagogue receptors in human pituitary adenomas: polymerase chain reaction, triple in-situ hybridization and cell culture studies. Journal of Neuroendocrinology $\mathbf{1 1}$ 491-502. (doi:10.1046/j.1365-2826.1999.00351.x)

Barnett BP, Hwang Y, Taylor MS, Kirchner H, Pfluger PT, Bernard V, Lin YY, Bowers EM, Mukherjee C, Song WJ et al. 2010 Glucose and weight control in mice with a designed ghrelin $\mathrm{O}$-acyltransferase inhibitor. Science 330 1689-1692. (doi:10.1126/science.1196154)

Barreiro ML, Pinilla L, Aguilar E \& Tena-Sempere M 2002 Expression and homologous regulation of GH secretagogue receptor mRNA in rat adrenal gland. European Journal of Endocrinology 147 677-688. (doi:10.1530/eje.0.1470677)

Barzon L, Pacenti M, Masi G, Stefani AL, Fincati K \& Palu G 2005 Loss of growth hormone secretagogue receptor $1 \mathrm{a}$ and overexpression of type $1 \mathrm{~b}$ receptor transcripts in human adrenocortical tumors. Oncology 68 414-421. (doi:10.1159/000086983)

Bassil AK, Haglund Y, Brown J, Rudholm T, Hellstrom PM, Naslund E, Lee K \& Sanger GJ 2007 Little or no ability of obestatin to interact with ghrelin or modify motility in the rat gastrointestinal tract. British Journal of Pharmacology 150 58-64. (doi:10.1038/sj.bjp.0706969)

Beck-Peccoz P, Persani L, Mannavola D \& Campi I 2009 Pituitary tumours: TSH-secreting adenomas. Best Practice \& Research. Clinical Endocrinology \& Metabolism 23 597-606. (doi:10.1016/j.beem.2009.05.006)

Bednarek MA, Feighner SD, Pong SS, McKee KK, Hreniuk DL, Silva MV, Warren VA, Howard AD, Van Der Ploeg LH \& Heck JV 2000 Structurefunction studies on the new growth hormone-releasing peptide, ghrelin: minimal sequence of ghrelin necessary for activation of growth hormone secretagogue receptor 1a. Journal of Medicinal Chemistry 43 4370-4376. (doi:10.1021/jm0001727)

Bilgin HM, Tumer C, Diken H, Kelle M \& Sermet A 2008 Role of ghrelin in the regulation of gastric acid secretion involving nitrergic mechanisms in rats. Physiological Research 57 563-568.

Bisaglia M, Greggio E, Beltramini M \& Bubacco L 2013 Dysfunction of dopamine homeostasis: clues in the hunt for novel Parkinson's disease therapies. FASEB Journal 27 2101-2110. (doi:10.1096/fj.12-226852)

Botla SK, Gholami AM, Malekpour M, Moskalev EA, Fallah M, Jandaghi P, Aghajani A, Bondar IS, Omranipour R, Malekpour F et al. 2012 Diagnostic values of GHSR DNA methylation pattern in breast cancer. Breast Cancer Research and Treatment 135 705-713. (doi:10.1007/ s10549-012-2197-z)

Bowers CY \& Granda-Ayala R 1996 GHRP-2, GHRH and SRIF interrelationships during chronic administration of GHRP-2 to humans. Journal of Pediatric Endocrinology \& Metabolism 9(Suppl 3) 261-270.

Broglio F, Arvat E, Benso A, Gottero C, Muccioli G, Papotti M, van der Lely AJ, Deghenghi R \& Ghigo E 2001 Ghrelin, a natural GH secretagogue produced by the stomach, induces hyperglycemia and reduces insulin secretion in humans. Journal of Clinical Endocrinology and Metabolism $\mathbf{8 6}$ 5083-5086. (doi:10.1210/jc.86.10.5083)
Broglio F, Benso A, Castiglioni C, Gottero C, Prodam F, Destefanis S, Gauna C, van der Lely AJ, Deghenghi R, Bo M et al. 2003 The endocrine response to ghrelin as a function of gender in humans in young and elderly subjects. Journal of Clinical Endocrinology and Metabolism $\mathbf{8 8}$ 1537-1542. (doi:10.1210/jc.2002-021504)

Bulgarelli I, Tamiazzo L, Bresciani E, Rapetti D, Caporali S, Lattuada D, Locatelli V \& Torsello A 2009 Desacyl-ghrelin and synthetic GHsecretagogues modulate the production of inflammatory cytokines in mouse microglia cells stimulated by $\beta$-amyloid fibrils. Journal of Neuroscience Research 87 2718-2727. (doi:10.1002/jnr.22088)

Camiña JP 2006 Cell biology of the ghrelin receptor. Journal of Neuroendocrinology 18 65-76. (doi:10.1111/j.1365-2826.2005.01379.x)

Cao Y, Tang J, Yang T, Ma H, Yi D, Gu C \& Yu S 2013 Cardioprotective effect of ghrelin in cardiopulmonary bypass involves a reduction in inflammatory response. PLOS ONE 8 e55021. (doi:10.1371/journal. pone.0055021)

Cappiello V, Ronchi C, Morpurgo PS, Epaminonda P, Arosio M, Beck-Peccoz P \& Spada A 2002 Circulating ghrelin levels in basal conditions and during glucose tolerance test in acromegalic patients. European Journal of Endocrinology 147 189-194. (doi:10.1530/ eje.0.1470189)

Carlini VP, Monzon ME, Varas MM, Cragnolini AB, Schioth HB, Scimonelli TN \& de Barioglio SR 2002 Ghrelin increases anxiety-like behavior and memory retention in rats. Biochemical and Biophysical Research Communications 299 739-743. (doi:10.1016/S0006-291X(02)02740-7)

Carlini VP, Varas MM, Cragnolini AB, Schioth HB, Scimonelli TN \& de Barioglio SR 2004 Differential role of the hippocampus, amygdala, and dorsal raphe nucleus in regulating feeding, memory, and anxiety-like behavioral responses to ghrelin. Biochemical and Biophysical Research Communications 313 635-641. (doi:10.1016/j.bbrc.2003.11.150)

Carlini VP, Ghersi M, Schioth HB \& de Barioglio SR 2010 Ghrelin and memory: differential effects on acquisition and retrieval. Peptides $\mathbf{3 1}$ 1190-1193. (doi:10.1016/j.peptides.2010.02.021)

Carraro G, Albertin G, Abudukerimu A, Aragona F \& Nussdorfer GG 2004 Growth hormone secretagogue receptor subtypes $1 \mathrm{a}$ and $1 \mathrm{~b}$ are expressed in the human adrenal cortex. International Journal of Molecular Medicine 13 295-298.

Carraro G, Albertin G, Aragona F, Forneris M, Casale V, Spinazzi R \& Nussdorfer GG 2006 Age-dependent decrease in the ghrelin gene expression in the human adrenal cortex: a real-time PCR study. International Journal of Molecular Medicine 17 319-321.

Cassoni P, Ghe C, Marrocco T, Tarabra E, Allia E, Catapano F, Deghenghi R, Ghigo E, Papotti M \& Muccioli G 2004 Expression of ghrelin and biological activity of specific receptors for ghrelin and des-acyl ghrelin in human prostate neoplasms and related cell lines. European Journal of Endocrinology 150 173-184. (doi:10.1530/eje.0.1500173)

Chaidarun SS \& Klibanski A 2002 Gonadotropinomas. Seminars in Reproductive Medicine 20 339-348. (doi:10.1055/s-2002-36708)

Chanclon B, Luque RM, Cordoba-Chacon J, Gahete MD, Pozo-Salas AI, Castaño JP, Gracia-Navarro F \& Martinez-Fuentes AJ 2013 Role of endogenous cortistatin in the regulation of ghrelin system expression at pancreatic level under normal and obese conditions. PLOS ONE $\mathbf{8}$ e57834. (doi:10.1371/journal.pone.0057834)

Chang SC \& Magee AI 2009 Acyltransferases for secreted signalling proteins (review). Molecular Membrane Biology 26 104-113. (doi:10.1080/ 09687680802706432)

Chang L, Ren Y, Liu X, Li WG, Yang J, Geng B, Weintraub NL \& Tang C 2004 Protective effects of ghrelin on ischemia/reperfusion injury in the isolated rat heart. Journal of Cardiovascular Pharmacology 43 165-170. (doi:10.1097/00005344-200402000-00001)

Chanoine JP, Wong AC \& Barrios V 2006 Obestatin, acylated and total ghrelin concentrations in the perinatal rat pancreas. Hormone Research 66 81-88. (doi:10.1159/000093585)

Chartrel N, Alvear-Perez R, Leprince J, Iturrioz X, Reaux-Le Goazigo A Audinot V, Chomarat P, Coge F, Nosjean O, Rodriguez M et al. 2007 Comment on 'Obestatin, a peptide encoded by the ghrelin gene, 
opposes ghrelin's effects on food intake'. Science $\mathbf{3 1 5} 766$ author reply 766. (doi:10.1126/science.1135047)

Chen L, Xing T, Wang M, Miao Y, Tang M, Chen J, Li G \& Ruan DY 2011 Local infusion of ghrelin enhanced hippocampal synaptic plasticity and spatial memory through activation of phosphoinositide 3-kinase in the dentate gyrus of adult rats. European Journal of Neuroscience $\mathbf{3 3}$ 266-275. (doi:10.1111/j.1460-9568.2010.07491.x)

Chopin LK, Seim I, Walpole CM \& Herington AC 2012 The ghrelin axis does it have an appetite for cancer progression? Endocrine Reviews 33 849-891. (doi:10.1210/er.2011-1007)

Chuang JC, Sakata I, Kohno D, Perello M, Osborne-Lawrence S, Repa JJ \& Zigman JM 2011 Ghrelin directly stimulates glucagon secretion from pancreatic $\alpha$-cells. Molecular Endocrinology 25 1600-1611. (doi:10.1210/ me.2011-1001)

Chung H, Kim E, Lee DH, Seo S, Ju S, Lee D, Kim H \& Park S 2007 Ghrelin inhibits apoptosis in hypothalamic neuronal cells during oxygenglucose deprivation. Endocrinology 148 148-159. (doi:10.1210/ en.2006-0991)

Chung H, Seo S, Moon M \& Park S 2008 Phosphatidylinositol-3-kinase/ Akt/glycogen synthase kinase-3 $\beta$ and ERK1/2 pathways mediate protective effects of acylated and unacylated ghrelin against oxygenglucose deprivation-induced apoptosis in primary rat cortical neuronal cells. Journal of Endocrinology 198 511-521. (doi:10.1677/JOE-08-0160)

Clark RG, Thomas GB, Mortensen DL, Won WB, Ma YH, Tomlinson EE, Fairhall KM \& Robinson IC 1997 Growth hormone secretagogues stimulate the hypothalamic-pituitary-adrenal axis and are diabetogenic in the Zucker diabetic fatty rat. Endocrinology 138 4316-4323. (doi:10.1210/en.138.10.4316)

Coiro V, Saccani-Jotti G, Minelli R, Melani A, Milli B, Manfredi G, Volpi R \& Chiodera P 2005 Adrenocorticotropin/cortisol and argininevasopressin secretory patterns in response to ghrelin in normal men. Neuroendocrinology 81 103-106. (doi:10.1159/000085541)

Coiro V, Saccani-Jotti G, Rubino P, Manfredi G, Vacca P, Volta E \& Chiodera P 2008 Oxytocin inhibits the stimulatory effect of ghrelin on circulating neuropeptide Y levels in humans. Journal of Neural Transmission 115 1265-1267. (doi:10.1007/s00702-008-0057-0)

Coiro V, Volpi R, Stella A, Cataldo S \& Chiodera P 2011 Oxytocin does not modify GH, ACTH, cortisol and prolactin responses to ghrelin in normal men. Neuropeptides 45 139-142. (doi:10.1016/j.npep. 2010.12.007)

Colao A 2009 Pituitary tumours: the prolactinoma. Best Practice \& Research. Clinical Endocrinology \& Metabolism 23 575-596. (doi:10.1016/j.beem. 2009.05.003)

Colao A, Di Somma C, Pivonello R, Faggiano A, Lombardi G \& Savastano S 2008 Medical therapy for clinically non-functioning pituitary adenomas. Endocrine-Related Cancer 15 905-915. (doi:10.1677/ERC-08-0181)

Cong WN, Golden E, Pantaleo N, White CM, Maudsley S \& Martin B 2010 Ghrelin receptor signaling: a promising therapeutic target for metabolic syndrome and cognitive dysfunction. CNS \& Neurological Disorders Drug Targets 9 557-563. (doi:10.2174/187152710793361513)

Cordoba-Chacon J, Gahete MD, Pozo-Salas AI, Martinez-Fuentes AJ, de Lecea L, Gracia-Navarro F, Kineman RD, Castaño JP \& Luque RM 2011 Cortistatin is not a somatostatin analogue but stimulates prolactin release and inhibits GH and ACTH in a gender-dependent fashion: potential role of ghrelin. Endocrinology 152 4800-4812. (doi:10.1210/en.2011-1542)

de la Cour CD, Norlen P \& Hakanson R 2007 Secretion of ghrelin from rat stomach ghrelin cells in response to local microinfusion of candidate messenger compounds: a microdialysis study. Regulatory Peptides 143 118-126. (doi:10.1016/j.regpep.2007.05.001)

Cummings DE, Purnell JQ, Frayo RS, Schmidova K, Wisse BE \& Weigle DS 2001 A preprandial rise in plasma ghrelin levels suggests a role in meal initiation in humans. Diabetes 50 1714-1719. (doi:10.2337/diabetes. 50.8.1714)

Damjanovic SS, Lalic NM, Pesko PM, Petakov MS, Jotic A, Miljic D, Lalic KS, Lukic L, Djurovic M \& Djukic VB 2006 Acute effects of ghrelin on insulin secretion and glucose disposal rate in gastrectomized patients. Journal of Clinical Endocrinology and Metabolism 91 2574-2581. (doi:10.1210/jc.2005-1482)

Date Y, Nakazato M, Hashiguchi S, Dezaki K, Mondal MS, Hosoda H, Kojima M, Kangawa K, Arima T, Matsuo H et al. 2002 Ghrelin is present in pancreatic $\alpha$-cells of humans and rats and stimulates insulin secretion. Diabetes 51 124-129. (doi:10.2337/diabetes.51.1.124)

De Vriese C, Grégoire F, De Neef P, Robberecht P \& Delporte C 2005 Ghrelin is produced by the human erythroleukemic HEL cell line and involved in an autocrine pathway leading to cell proliferation. Endocrinology 146 1514-1522. (doi:10.1210/en.2004-0964)

Dezaki K, Hosoda H, Kakei M, Hashiguchi S, Watanabe M, Kangawa K \& Yada T 2004 Endogenous ghrelin in pancreatic islets restricts insulin release by attenuating $\mathrm{Ca}^{2+}$ signaling in $\beta$-cells: implication in the glycemic control in rodents. Diabetes 53 3142-3151. (doi:10.2337/ diabetes.53.12.3142)

Diano S, Farr SA, Benoit SC, McNay EC, da Silva I, Horvath B, Gaskin FS, Nonaka N, Jaeger LB, Banks WA et al. 2006 Ghrelin controls hippocampal spine synapse density and memory performance. Nature Neuroscience 9 381-388. (doi:10.1038/nn1656)

Diaz-Lezama N, Hernandez-Elvira M, Sandoval A, Monroy A, Felix R \& Monjaraz E 2010 Ghrelin inhibits proliferation and increases T-type $\mathrm{Ca}^{2+}$ channel expression in PC-3 human prostate carcinoma cells. Biochemical and Biophysical Research Communications 403 24-29. (doi:10.1016/j.bbrc.2010.10.100)

Dixit VD \& Taub DD 2005 Ghrelin and immunity: a young player in an old field. Experimental Gerontology 40 900-910. (doi:10.1016/j.exger.2005. 09.003)

Dixit VD, Yang H, Sun Y, Weeraratna AT, Youm YH, Smith RG \& Taub DD 2007 Ghrelin promotes thymopoiesis during aging. Journal of Clinical Investigation 117 2778-2790. (doi:10.1172/JCI30248)

Dornonville de la Cour C, Lindstrom E, Norlen P \& Hakanson R 2004 Ghrelin stimulates gastric emptying but is without effect on acid secretion and gastric endocrine cells. Regulatory Peptides 120 23-32. (doi:10.1016/j.regpep.2004.02.008)

Dos Santos VV, Rodrigues AL, De Lima TC, de Barioglio SR, Raisman-Vozari R \& Prediger RD 2013 Ghrelin as a neuroprotective and palliative agent in Alzheimer's and Parkinson's disease. Current Pharmaceutical Design 19 6773-6790. (doi:10.2174/13816128113199990411)

Dossus L, McKay JD, Canzian F, Wilkening S, Rinaldi S, Biessy C, Olsen A, Tjonneland A, Jakobsen MU, Overvad K et al. 2008 Polymorphisms of genes coding for ghrelin and its receptor in relation to anthropometry, circulating levels of IGF-I and IGFBP-3, and breast cancer risk: a casecontrol study nested within the European Prospective Investigation into Cancer and Nutrition (EPIC). Carcinogenesis 29 1360-1366. (doi:10.1093/carcin/bgn083)

Duxbury MS, Waseem T, Ito H, Robinson MK, Zinner MJ, Ashley SW \& Whang EE 2003 Ghrelin promotes pancreatic adenocarcinoma cellular proliferation and invasiveness. Biochemical and Biophysical Research Communications 309 464-468. (doi:10.1016/j.bbrc.2003. 08.024)

Egido EM, Rodriguez-Gallardo J, Silvestre RA \& Marco J 2002 Inhibitory effect of ghrelin on insulin and pancreatic somatostatin secretion. European Journal of Endocrinology 146 241-244. (doi:10.1530/ eje.0.1460241)

Egido EM, Hernandez R, Marco J \& Silvestre RA 2009 Effect of obestatin on insulin, glucagon and somatostatin secretion in the perfused rat pancreas. Regulatory Peptides 152 61-66. (doi:10.1016/j.regpep.2008. 08.003)

Ekeblad S, Lejonklou MH, Grimfjard P, Johansson T, Eriksson B, Grimelius L, Stridsberg M, Stalberg P \& Skogseid B 2007 Co-expression of ghrelin and its receptor in pancreatic endocrine tumours. Clinical Endocrinology 66 115-122.

Feelders RA \& Hofland LJ 2013 Medical treatment of Cushing's disease. Journal of Clinical Endocrinology and Metabolism 98 425-438. (doi:10.1210/jc.2012-3126) 
Feng DD, Yang SK, Loudes C, Simon A, Al-Sarraf T, Culler M, Alvear-Perez R, Llorens-Cortes C, Chen C, Epelbaum J et al. 2011 Ghrelin and obestatin modulate growth hormone-releasing hormone release and synaptic inputs onto growth hormone-releasing hormone neurons. European Journal of Neuroscience 34 732-744. (doi:10.1111/j.1460-9568.2011. 07787.x)

Fernandez-Fernandez R, Tena-Sempere M, Navarro VM, Barreiro ML, Castellano JM, Aguilar E \& Pinilla L 2005 Effects of ghrelin upon gonadotropin-releasing hormone and gonadotropin secretion in adult female rats: in vivo and in vitro studies. Neuroendocrinology 82 245-255. (doi:10.1159/000092753)

Frago LM, Paneda C, Dickson SL, Hewson AK, Argente J \& Chowen JA 2002 Growth hormone $(\mathrm{GH})$ and $\mathrm{GH}$-releasing peptide- 6 increase brain insulin-like growth factor-I expression and activate intracellular signaling pathways involved in neuroprotection. Endocrinology 143 4113-4122. (doi:10.1210/en.2002-220261)

Freda PU, Reyes CM, Conwell IM, Sundeen RE \& Wardlaw SL 2003 Serum ghrelin levels in acromegaly: effects of surgical and long-acting octreotide therapy. Journal of Clinical Endocrinology and Metabolism $\mathbf{8 8}$ 2037-2044. (doi:10.1210/jc.2002-021683)

Fujino K, Inui A, Asakawa A, Kihara N, Fujimura M \& Fujimiya M 2003 Ghrelin induces fasted motor activity of the gastrointestinal tract in conscious fed rats. Journal of Physiology 550 227-240. (doi:10.1113/ jphysiol.2003.040600)

Fujitsuka N, Asakawa A, Amitani H, Fujimiya M \& Inui A 2012 Ghrelin and gastrointestinal movement. Methods in Enzymology 514 289-301. (doi:10.1016/B978-0-12-381272-8.00018-0)

Furuta M, Funabashi T \& Kimura F 2001 Intracerebroventricular administration of ghrelin rapidly suppresses pulsatile luteinizing hormone secretion in ovariectomized rats. Biochemical and Biophysical Research Communications 288 780-785. (doi:10.1006/bbrc.2001.5854)

Gahete MD, Cordoba-Chacon J, Salvatori R, Castaño JP, Kineman RD \& Luque RM 2010 $a$ Metabolic regulation of ghrelin $\mathrm{O}$-acyl transferase (GOAT) expression in the mouse hypothalamus, pituitary, and stomach. Molecular and Cellular Endocrinology 317 154-160. (doi:10.1016/j.mce.2009.12.023)

Gahete MD, Rubio A, Cordoba-Chacon J, Gracia-Navarro F, Kineman RD Avila J, Luque RM \& Castaño JP $2010 b$ Expression of the ghrelin and neurotensin systems is altered in the temporal lobe of Alzheimer's disease patients. Journal of Alzheimer's Disease 22 819-828. (doi:10.3233/JAD-2010-100873)

Gahete MD, Cordoba-Chacon J, Hergueta-Redondo M, Martinez-Fuentes AJ, Kineman RD, Moreno-Bueno G, Luque RM \& Castaño JP $2011 a$ A novel human ghrelin variant (In1-ghrelin) and ghrelin-Oacyltransferase are overexpressed in breast cancer: potential pathophysiological relevance. PLOS ONE 6 e23302. (doi:10.1371/ journal.pone.0023302)

Gahete MD, Cordoba-Chacon J, Kineman RD, Luque RM \& Castaño JP $2011 b$ Role of ghrelin system in neuroprotection and cognitive functions: implications in Alzheimer's disease. Peptides 32 2225-2228. (doi:10.1016/j.peptides.2011.09.019)

Garg A 2007 The ongoing saga of obestatin: is it a hormone? Journal of Clinical Endocrinology and Metabolism 92 3396-3398. (doi:10.1210/ jc.2007-0999)

Gargantini E, Grande C, Trovato L, Ghigo E \& Granata R 2013 The role of obestatin in glucose and lipid metabolism. Hormone and Metabolic Research [in press]. (doi:10.1055/s-0033-1351325)

Garin MC, Burns CM, Kaul S \& Cappola AR 2013 Clinical review: the human experience with ghrelin administration. Journal of Clinical Endocrinology and Metabolism 98 1826-1837. (doi:10.1210/ jc.2012-4247)

Ghelardoni S, Carnicelli V, Frascarelli S, Ronca-Testoni S \& Zucchi R 2006 Ghrelin tissue distribution: comparison between gene and protein expression. Journal of Endocrinological Investigation 29 115-121.

Giordano R, Pellegrino M, Picu A, Bonelli L, Balbo M, Berardelli R, Lanfranco F, Ghigo E \& Arvat E 2006 Neuroregulation of the

http://joe.endocrinology-journals.org DOI: 10.1530/JOE-13-0391 (c) 2014 Society for Endocrinology Printed in Great Britain hypothalamus-pituitary-adrenal (HPA) axis in humans: effects of GABA-, mineralocorticoid-, and GH-secretagogue-receptor modulation. Scientific World Journal 6 1-11. (doi:10.1100/tsw.2006.09)

Glavaski-Joksimovic A, Jeftinija K, Scanes CG, Anderson LL \& Jeftinija S 2003 Stimulatory effect of ghrelin on isolated porcine somatotropes. Neuroendocrinology 77 367-379. (doi:10.1159/000071309)

Gnanapavan S, Kola B, Bustin SA, Morris DG, McGee P, Fairclough P, Bhattacharya S, Carpenter R, Grossman AB \& Korbonits M 2002 The tissue distribution of the mRNA of ghrelin and subtypes of its receptor, GHS-R, in humans. Journal of Clinical Endocrinology and Metabolism $\mathbf{8 7}$ 2988. (doi:10.1210/jc.87.6.2988)

Gong Y, Xu L, Guo F, Pang M, Shi Z, Gao S \& Sun X 2013 Effects of ghrelin on gastric distension sensitive neurons and gastric motility in the lateral septum and arcuate nucleus regulation. Journal of Gastroenterology [in press]. (doi:10.1007/s00535-013-0789-y)

Gourcerol G \& Tache Y 2007 Obestatin - a ghrelin-associated peptide that does not hold its promise to suppress food intake and motility. Neurogastroenterology and Motility 19 161-165. (doi:10.1111/j.13652982.2007.00916.x)

Granata R, Settanni F, Biancone L, Trovato L, Nano R, Bertuzzi F, Destefanis S, Annunziata M, Martinetti M, Catapano F et al. 2007 Acylated and unacylated ghrelin promote proliferation and inhibit apoptosis of pancreatic $\beta$-cells and human islets: involvement of $3^{\prime}, 5^{\prime}$-cyclic adenosine monophosphate/protein kinase A, extracellular signal-regulated kinase $1 / 2$, and phosphatidyl inositol 3-kinase/Akt signaling. Endocrinology 148 512-529. (doi:10.1210/en.2006-0266)

Granata R, Settanni F, Gallo D, Trovato L, Biancone L, Cantaluppi V, Nano R, Annunziata M, Campiglia P, Arnoletti E et al. 2008 Obestatin promotes survival of pancreatic $\beta$-cells and human islets and induces expression of genes involved in the regulation of $\beta$-cell mass and function. Diabetes 57 967-979. (doi:10.2337/db07-1104)

Granata R, Gallo D, Luque RM, Baragli A, Scarlatti F, Grande C, Gesmundo I, Cordoba-Chacon J, Bergandi L, Settanni F et al. 2012 Obestatin regulates adipocyte function and protects against diet-induced insulin resistance and inflammation. FASEB Journal 26 3393-3411. (doi:10.1096/fj.11-201343)

Grey CL \& Chang JP 2011 Differential involvement of protein kinase C and protein kinase A in ghrelin-induced growth hormone and gonadotrophin release from goldfish (Carassius auratus) pituitary cells. Journal of Neuroendocrinology 23 1273-1287. (doi:10.1111/j.1365-2826. 2011.02221.x)

Grey CL \& Chang JP 2013a Differential modulation of ghrelin-induced GH and LH release by PACAP and dopamine in goldfish pituitary cells. General and Comparative Endocrinology 191 215-224. (doi:10.1016/ j.ygcen.2013.06.020)

Grey CL \& Chang JP $2013 b$ Growth hormone-releasing hormone stimulates GH release while inhibiting ghrelin- and sGnRH-induced LH release from goldfish pituitary cells. General and Comparative Endocrinology 186 150-156. (doi:10.1016/j.ygcen.2013.02.037)

Gronberg M, Tsolakis AV, Magnusson L, Janson ET \& Saras J 2008 Distribution of obestatin and ghrelin in human tissues: immunoreactive cells in the gastrointestinal tract, pancreas, and mammary glands. Journal of Histochemistry \& Cytochemistry 56 793-801. (doi:10.1369/jhc.2008.951145)

Gronberg M, Fjallskog ML, Jirstrom K \& Janson ET 2012 Expression of ghrelin is correlated to a favorable outcome in invasive breast cancer. Acta Oncologica 51 386-393. (doi:10.3109/0284186X.2011.631576)

Gualillo O, Lago F \& Dieguez C 2008 Introducing GOAT: a target for obesity and anti-diabetic drugs? Trends in Pharmacological Sciences 29 398-401. (doi:10.1016/j.tips.2008.06.003)

Guan XM, Yu H, Palyha OC, McKee KK, Feighner SD, Sirinathsinghji DJ, Smith RG, Van der Ploeg LH \& Howard AD 1997 Distribution of mRNA encoding the growth hormone secretagogue receptor in brain and peripheral tissues. Brain Research. Molecular Brain Research 48 23-29. (doi:10.1016/S0169-328X(97)00071-5) 
Gutierrez JA, Solenberg PJ, Perkins DR, Willency JA, Knierman MD, Jin Z, Witcher DR, Luo S, Onyia JE \& Hale JE 2008 Ghrelin octanoylation mediated by an orphan lipid transferase. PNAS 105 6320-6325. (doi:10.1073/pnas.0800708105)

Hassouna R, Zizzari P, Viltart O, Yang SK, Gardette R, Videau C, Badoer E, Epelbaum J \& Tolle V 2012 A natural variant of obestatin, Q90L, inhibits ghrelin's action on food intake and GH secretion and targets NPY and GHRH neurons in mice. PLoS ONE 7 e51135. (doi:10.1371/ journal.pone.0051135)

Hataya Y, Akamizu T, Takaya K, Kanamoto N, Ariyasu H, Saijo M, Moriyama K, Shimatsu A, Kojima M, Kangawa K et al. 2001 A low dose of ghrelin stimulates growth hormone (GH) release synergistically with GH-releasing hormone in humans. Journal of Clinical Endocrinology and Metabolism 86 4552. (doi:10.1210/jc.86.9.4552)

Hattori N 2009 Expression, regulation and biological actions of growth hormone (GH) and ghrelin in the immune system. Growth Hormone \& IGF Research 19 187-197. (doi:10.1016/j.ghir.2008.12.001)

Hattori N, Saito T, Yagyu T, Jiang BH, Kitagawa K \& Inagaki C 2001 GH, GH receptor, GH secretagogue receptor, and ghrelin expression in human $\mathrm{T}$ cells, B cells, and neutrophils. Journal of Clinical Endocrinology and Metabolism 86 4284-4291. (doi:10.1210/jc.86.9.4284)

Heppner KM, Muller TD, Kirchner H, Perez-Tilve D, Pfluger PT, Tschop MH \& Hofmann SM 2013 The role of ghrelin-octanoyl-acyl-transferase in thermoregulation. Journal of Endocrinological Investigation 36 180-184.

Hosomi S, Oshitani N, Kamata N, Sogawa M, Yamagami H, Watanabe K, Tominaga K, Watanabe T, Fujiwara Y, Maeda K et al. 2008 Phenotypical and functional study of ghrelin and its receptor in the pathogenesis of Crohn's disease. Inflammatory Bowel Diseases 14 1205-1213. (doi:10.1002/ibd.20477)

Howard AD, Feighner SD, Cully DF, Arena JP, Liberator PA, Rosenblum CI, Hamelin M, Hreniuk DL, Palyha OC, Anderson J et al. 1996 A receptor in pituitary and hypothalamus that functions in growth hormone release. Science 273 974-977. (doi:10.1126/science.273.5277.974)

Iglesias MJ, Pineiro R, Blanco M, Gallego R, Dieguez C, Gualillo O, Gonzalez-Juanatey JR \& Lago F 2004 Growth hormone releasing peptide (ghrelin) is synthesized and secreted by cardiomyocytes. Cardiovascular Research 62 481-488. (doi:10.1016/ j.cardiores.2004.01.024)

Inhoff T, Monnikes H, Noetzel S, Stengel A, Goebel M, Dinh QT, Riedl A, Bannert N, Wisser AS, Wiedenmann B et al. 2008 Desacyl ghrelin inhibits the orexigenic effect of peripherally injected ghrelin in rats. Peptides 29 2159-2168. (doi:10.1016/j.peptides.2008.09.014)

Isgaard J \& Granata R 2011 Ghrelin in cardiovascular disease and atherogenesis. Molecular and Cellular Endocrinology 340 59-64. (doi:10.1016/j.mce.2011.03.006)

Ishizaki S, Murase T, Sugimura Y, Kakiya S, Yokoi H, Tachikawa K, Arima H, Miura Y \& Oiso Y 2002 Role of ghrelin in the regulation of vasopressin release in conscious rats. Endocrinology 143 1589-1593. (doi:10.1210/ en.143.5.1589)

Isidro ML, Nemina R, Garcia-Buela J, Sangiao-Alvarellos S \& Cordido F 2007 Effect of oral glucose on acylated and total ghrelin secretion in acromegalic patients. Neuroendocrinology Letters 28 596-603.

Jarkovska Z, Rosicka M, Marek J, Hana V, Weiss V, Justova V, Lacinova Z, Haluzik M \& Krsek M 2006 Plasma levels of total and active ghrelin in acromegaly and growth hormone deficiency. Physiological Research $\mathbf{5 5}$ 175-181.

Jaskula M, Wasko R, Komarowska H, Dziubandowska A \& Sowinski J 2009 Serum ghrelin levels and disturbances of the lipid profile in patients with acromegaly. Neuroendocrinology Letters 30 245-255.

Jaszberenyi M, Bujdoso E, Bagosi Z \& Telegdy G 2006 Mediation of the behavioral, endocrine and thermoregulatory actions of ghrelin. Hormones and Behavior 50 266-273. (doi:10.1016/j.yhbeh.2006.03.010)

Jeffery PL, Herington AC \& Chopin LK 2002 Expression and action of the growth hormone releasing peptide ghrelin and its receptor in prostate cancer cell lines. Journal of Endocrinology 172 R7-11. (doi:10.1677/joe.0. 172R007)
Jeffery PL, Murray RE, Yeh AH, McNamara JF, Duncan RP, Francis GD, Herington AC \& Chopin LK 2005 Expression and function of the ghrelin axis, including a novel preproghrelin isoform, in human breast cancer tissues and cell lines. Endocrine-Related Cancer 12 839-850. (doi:10.1677/erc.1.00984)

Jiang H, Li LJ, Wang J \& Xie JX 2008 Ghrelin antagonizes MPTP-induced neurotoxicity to the dopaminergic neurons in mouse substantia nigra. Experimental Neurology 212 532-537. (doi:10.1016/j.expneurol.2008. 05.006)

Jonsson E 2013 The role of ghrelin in energy balance regulation in fish. General and Comparative Endocrinology 187 79-85. (doi:10.1016/j.ygcen. 2013.03.013)

Kageyama H, Funahashi H, Hirayama M, Takenoya F, Kita T, Kato S, Sakurai J, Lee EY, Inoue S, Date Y et al. 2005 Morphological analysis of ghrelin and its receptor distribution in the rat pancreas. Regulatory Peptides 126 67-71. (doi:10.1016/j.regpep.2004.08.031)

Kaiya H, Miyazato M, Kangawa K, Peter RE \& Unniappan S 2008 Ghrelin: a multifunctional hormone in non-mammalian vertebrates. Comparative Biochemistry and Physiology. Part A, Molecular \& Integrative Physiology 149 109-128. (doi:10.1016/j.cbpa.2007.12.004)

Kawamata T, Inui A, Hosoda H, Kangawa K \& Hori T 2007 Perioperative plasma active and total ghrelin levels are reduced in acromegaly when compared with in nonfunctioning pituitary tumours even after normalization of serum GH. Clinical Endocrinology 67 140-144. (doi:10.1111/j.1365-2265.2007.02851.x)

Kenny R, Cai G, Bayliss JA, Clarke M, Choo YL, Miller AA, Andrews ZB \& Spencer SJ 2013 Endogenous ghrelin's role in hippocampal neuroprotection after global cerebral ischemia: does endogenous ghrelin protect against global stroke? American Journal of Physiology. Regulatory, Integrative and Comparative Physiology 304 R980-R990. (doi:10.1152/ajpregu.00594.2012)

Kim K, Arai K, Sanno N, Osamura RY, Teramoto A \& Shibasaki T 2001 Ghrelin and growth hormone (GH) secretagogue receptor (GHSR) mRNA expression in human pituitary adenomas. Clinical Endocrinology 54 759-768. (doi:10.1046/j.1365-2265.2001.01286.x)

Kineman RD \& Luque RM 2007 Evidence that ghrelin is as potent as growth hormone $(\mathrm{GH})$-releasing hormone (GHRH) in releasing $\mathrm{GH}$ from primary pituitary cell cultures of a nonhuman primate (Papio anubis), acting through intracellular signaling pathways distinct from GHRH. Endocrinology 148 4440-4449. (doi:10.1210/en.2007-0441)

Kineman RD, Gahete MD \& Luque RM 2007 Identification of a mouse ghrelin gene transcript that contains intron 2 and is regulated in the pituitary and hypothalamus in response to metabolic stress. Journal of Molecular Endocrinology 38 511-521. (doi:10.1677/JME-06-0026)

Kirchner H, Heppner KM \& Tschop MH 2012 The role of ghrelin in the control of energy balance. Handbook of Experimental Pharmacology 209 161-184. (doi:10.1007/978-3-642-24716-3_7)

Kishimoto I, Tokudome T, Hosoda H, Miyazato M \& Kangawa K 2012 Ghrelin and cardiovascular diseases. Journal of Cardiology 59 8-13. (doi:10.1016/j.jjcc.2011.11.002)

Kleinz MJ, Maguire JJ, Skepper JN \& Davenport AP 2006 Functional and immunocytochemical evidence for a role of ghrelin and des-octanoyl ghrelin in the regulation of vascular tone in man. Cardiovascular Research 69 227-235. (doi:10.1016/j.cardiores.2005.09.001)

Kluge M, Schussler P, Uhr M, Yassouridis A \& Steiger A 2007 Ghrelin suppresses secretion of luteinizing hormone in humans. Journal of Clinical Endocrinology and Metabolism 92 3202-3205. (doi:10.1210/ jc. 2007-0593)

Kluge M, Uhr M, Bleninger P, Yassouridis A \& Steiger A 2009 Ghrelin suppresses secretion of FSH in males. Clinical Endocrinology 70 920-923. (doi:10.1111/j.1365-2265.2008.03440.x)

Kluge M, Riedl S, Uhr M, Schmidt D, Zhang X, Yassouridis A \& Steiger A 2010 Ghrelin affects the hypothalamus-pituitary-thyroid axis in humans by increasing free thyroxine and decreasing TSH in plasma. European Journal of Endocrinology 162 1059-1065. (doi:10.1530/ EJE-10-0094) 
Kluge M, Schussler P, Schmidt D, Uhr M \& Steiger A 2012 Ghrelin suppresses secretion of luteinizing hormone (LH) and folliclestimulating hormone (FSH) in women. Journal of Clinical Endocrinology and Metabolism 97 E448-E451. (doi:10.1210/jc.2011-2607)

Kobelt P, Wisser AS, Stengel A, Goebel M, Bannert N, Gourcerol G, Inhoff T, Noetzel S, Wiedenmann B, Klapp BF et al. 2008 Peripheral obestatin has no effect on feeding behavior and brain Fos expression in rodents. Peptides 29 1018-1027. (doi:10.1016/j.peptides.2008.01.020)

Kojima M, Hosoda H, Date Y, Nakazato M, Matsuo H \& Kangawa K 1999 Ghrelin is a growth-hormone-releasing acylated peptide from stomach. Nature 402 656-660. (doi:10.1038/45230)

Korbonits M, Trainer PJ \& Besser GM 1995 The effect of an opiate antagonist on the hormonal changes induced by hexarelin. Clinical Endocrinology 43 365-371. (doi:10.1111/j.1365-2265.1995.tb02045.x)

Korbonits M, Jacobs RA, Aylwin SJ, Burrin JM, Dahia PL, Monson JP, Honegger J, Fahlbush R, Trainer PJ, Chew SL et al. 1998 Expression of the growth hormone secretagogue receptor in pituitary adenomas and other neuroendocrine tumors. Journal of Clinical Endocrinology and Metabolism 83 3624-3630. (doi:10.1210/jc.83.10.3624)

Korbonits M, Kaltsas G, Perry LA, Putignano P, Grossman AB, Besser GM \& Trainer PJ 1999 The growth hormone secretagogue hexarelin stimulates the hypothalamo-pituitary-adrenal axis via arginine vasopressin. Journal of Clinical Endocrinology and Metabolism 84 2489-2495. (doi:10.1210/jc.84.7.2489)

Korbonits M, Bustin SA, Kojima M, Jordan S, Adams EF, Lowe DG, Kangawa K \& Grossman AB 2001 The expression of the growth hormone secretagogue receptor ligand ghrelin in normal and abnormal human pituitary and other neuroendocrine tumors. Journal of Clinical Endocrinology and Metabolism 86 881-887. (doi:10.1210/jc.86.2.881)

Korbonits M, Goldstone AP, Gueorguiev M \& Grossman AB 2004 Ghrelin a hormone with multiple functions. Frontiers in Neuroendocrinology $\mathbf{2 5}$ 27-68. (doi:10.1016/j.yfrne.2004.03.002)

Lacerda-Miranda G, Soares VM, Vieira AK, Lessa JG, Rodrigues-Cunha AC, Cortez E, Garcia-Souza EP \& Moura AS 2012 Ghrelin signaling in heart remodeling of adult obese mice. Peptides 35 65-73. (doi:10.1016/ j.peptides.2012.02.025)

Lanfranco F, Bonelli L, Baldi M, Me E, Broglio F \& Ghigo E 2008 Acylated ghrelin inhibits spontaneous luteinizing hormone pulsatility and responsiveness to naloxone but not that to gonadotropin-releasing hormone in young men: evidence for a central inhibitory action of ghrelin on the gonadal axis. Journal of Clinical Endocrinology and Metabolism 93 3633-3639. (doi:10.1210/jc.2008-0049)

Langston JW \& Ballard PA Jr 1983 Parkinson's disease in a chemist working with 1-methyl-4-phenyl-1,2,5,6-tetrahydropyridine. New England Journal of Medicine 309310.

Lauwers E, Landuyt B, Arckens L, Schoofs L \& Luyten W 2006 Obestatin does not activate orphan $\mathrm{G}$ protein-coupled receptor GPR39. Biochemical and Biophysical Research Communications 351 21-25. (doi:10.1016/j.bbrc.2006.09.141)

Lawnicka H, Melen-Mucha G, Motylewska E, Mucha S \& Stepien H 2012 Modulation of ghrelin axis influences the growth of colonic and prostatic cancer cells in vitro. Pharmacological Reports 64 951-959.

Lawrence CB, Snape AC, Baudoin FM \& Luckman SM 2002 Acute central ghrelin and GH secretagogues induce feeding and activate brain appetite centers. Endocrinology 143 155-162. (doi:10.1210/en.143.1.155)

Lear PV, Iglesias MJ, Feijóo-Bandín S, Rodríguez-Penas D, Mosquera-Leal A, García-Rúa V, Gualillo O, Ghè C, Arnoletti E, Muccioli G et al. 2010 Desacyl ghrelin has specific binding sites and different metabolic effects from ghrelin in cardiomyocytes. Endocrinology 151 3286-3298. (doi:10.1210/en.2009-1205)

Lee HM, Wang G, Englander EW, Kojima M \& Greeley GH Jr 2002 Ghrelin, a new gastrointestinal endocrine peptide that stimulates insulin secretion: enteric distribution, ontogeny, influence of endocrine, and dietary manipulations. Endocrinology 143 185-190. (doi:10.1210/en.143.1.185)

Li E, Chung H, Kim Y, Kim DH, Ryu JH, Sato T, Kojima M \& Park S 2013 Ghrelin directly stimulates adult hippocampal neurogenesis: implications for learning and memory. Endocrine Journal 60 781-789 (doi:10.1507/endocrj.EJ13-0008)

Lim CT, Kola B, Grossman A \& Korbonits M 2011a The expression of ghrelin $O$-acyltransferase (GOAT) in human tissues. Endocrine Journal 58 707-710. (doi:10.1507/endocrj.K11E-117)

Lim CT, Kola B \& Korbonits M $2011 b$ The ghrelin/GOAT/GHS-R system and energy metabolism. Reviews in Endocrine \& Metabolic Disorders 12 173-186. (doi:10.1007/s11154-011-9169-1)

Liu Y, Wang PS, Xie D, Liu K \& Chen L 2006 Ghrelin reduces injury of hippocampal neurons in a rat model of cerebral ischemia/reperfusion. Chinese Journal of Physiology 49 244-250.

Liu B, Garcia EA \& Korbonits M 2011 Genetic studies on the ghrelin, growth hormone secretagogue receptor (GHSR) and ghrelin $O$-acyl transferase (GOAT) genes. Peptides 32 2191-2207. (doi:10.1016/ j.peptides.2011.09.006)

Luque RM \& Kineman RD 2007 Gender-dependent role of endogenous somatostatin in regulating growth hormone-axis function in mice. Endocrinology 148 5998-6006. (doi:10.1210/en.2007-0946)

Luque RM, Gahete MD, Hochgeschwender U \& Kineman RD 2006 Evidence that endogenous SST inhibits ACTH and ghrelin expression by independent pathways. American Journal of Physiology. Endocrinology and Metabolism 291 395-403. (doi:10.1152/ajpendo.00038.2006)

Maccarinelli G, Sibilia V, Torsello A, Raimondo F, Pitto M, Giustina A, Netti C \& Cocchi D 2005 Ghrelin regulates proliferation and differentiation of osteoblastic cells. Journal of Endocrinology 184 249-256. (doi:10.1677/ joe.1.05837)

Mafra D, Farage NE, Lobo JC, Stockler-Pinto MB, Leal VO, Carvalho DP \& Leite M Jr 2011 Relationship between total ghrelin and inflammation in hemodialysis patients. Peptides 32 358-361. (doi:10.1016/j.peptides. 2010.11.023)

Malagon MM, Luque RM, Ruiz-Guerrero E, Rodriguez-Pacheco F, GarciaNavarro S, Casanueva FF, Gracia-Navarro F \& Castaño JP 2003 Intracellular signaling mechanisms mediating ghrelin-stimulated growth hormone release in somatotropes. Endocrinology 144 5372-5380. (doi:10.1210/en.2003-0723)

Malendowicz W, Ziolkowska A, Szyszka M \& Kwias Z 2009 Elevated blood active ghrelin and unaltered total ghrelin and obestatin concentrations in prostate carcinoma. Urologia Internationalis 83 471-475. (doi:10.1159/000251190)

Marjchrzak K, Pawlowski KM, Orzechowska EJ, Dolka I, Mucha J, Motyl T \& Król M 2012 A role of ghrelin in canine mammary carcinoma cells proliferation, apoptosis and migration. BMC Veterinary Research $\mathbf{8} 170$. (doi:10.1186/1746-6148-8-170)

Martinez-Fuentes AJ, Moreno-Fernandez J, Vazquez-Martinez R, DuranPrado M, de la Riva A, Tena-Sempere M, Dieguez C, Jimenez-Reina L, Webb SM, Pumar A et al. 2006 Ghrelin is produced by and directly activates corticotrope cells from adrenocorticotropin-secreting adenomas. Journal of Clinical Endocrinology and Metabolism 91 2225-2231. (doi:10.1210/jc.2006-0235)

Masuda Y, Tanaka T, Inomata N, Ohnuma N, Tanaka S, Itoh Z, Hosoda H, Kojima M \& Kangawa K 2000 Ghrelin stimulates gastric acid secretion and motility in rats. Biochemical and Biophysical Research Communications 276 905-908. (doi:10.1006/bbrc.2000.3568)

Melmed S 2009 Acromegaly pathogenesis and treatment. Journal of Clinical Investigation 119 3189-3202. (doi:10.1172/JCI39375)

Messini CI, Dafopoulos K, Chalvatzas N, Georgoulias P, Anifandis G \& Messinis IE $2010 a$ Blockage of ghrelin-induced prolactin secretion in women by bromocriptine. Fertility and Sterility 94 1478-1481. (doi:10.1016/j.fertnstert.2009.08.032)

Messini CI, Dafopoulos K, Chalvatzas N, Georgoulias P, Anifandis G \& Messinis IE $2010 b$ Effect of ghrelin and thyrotropin-releasing hormone on prolactin secretion in normal women. Hormone and Metabolic Research 42 204-208. (doi:10.1055/s-0029-1241197)

Messini CI, Dafopoulos K, Chalvatzas N, Georgoulias P, Anifandis G \& Messinis IE 2011 Effect of ghrelin and metoclopramide on prolactin 
secretion in normal women. Journal of Endocrinological Investigation 34 276-279. (doi:10.3275/7102)

Miao Y, Xia Q, Hou Z, Zheng Y, Pan H \& Zhu S 2007 Ghrelin protects cortical neuron against focal ischemia/reperfusion in rats. Biochemical and Biophysical Research Communications 359 795-800. (doi:10.1016/ j.bbrc.2007.05.192)

Miljic D, Joksimovic M, Doknic M, Ivovic M, Djurovic M, Pekic S, Tancic M, Soldatovic I, Stojanovic M, Nale D et al. 2010 ACTH and cortisol responses to ghrelin and desmopressin in patients with Cushing's disease and adrenal enlargement. Journal of Endocrinological Investigation 33 526-529. (doi:10.3275/6812)

Milosevic V, Stevanovic DM, Nesic DM, Sosic-Jurjevic BT, Ajdzanovic VZ, Starcevic VP \& Severs WB 2010 Central effects of ghrelin on the adrenal cortex: a morphological and hormonal study. General Physiology and Biophysics 29 194-202. (doi:10.4149/gpb_2010_02_194)

Milosevic V, Ajdzanovic V, Nesic D, Starcevic V, Filipovic B, Rakocevic R \& Stevanovic D 2013 Central ghrelin treatment stimulates ACTH cells in normal-fed, food-restricted and high-fed rats: an immunohistomorphometric and hormonal study. Acta Histochemica 115 858-864. (doi:10.1016/j.acthis.2013.04.003)

Molfino A, Gioia G \& Muscaritoli M 2013 The hunger hormone ghrelin in cachexia. Expert Opinion on Biological Therapy 13 465-468. (doi:10.1517/ 14712598.2013.748031)

Moon M, Kim HG, Hwang L, Seo JH, Kim S, Hwang S, Lee D, Chung H, Oh MS, Lee KT et al. 2009 Neuroprotective effect of ghrelin in the 1-methyl4-phenyl-1,2,3,6-tetrahydropyridine mouse model of Parkinson's disease by blocking microglial activation. Neurotoxicity Research $\mathbf{1 5}$ 332-347. (doi:10.1007/s12640-009-9037-x)

Muccioli G, Tschop M, Papotti M, Deghenghi R, Heiman M \& Ghigo E 2002 Neuroendocrine and peripheral activities of ghrelin: implications in metabolism and obesity. European Journal of Pharmacology 440 235-254. (doi:10.1016/S0014-2999(02)01432-2)

Muller TD, Tschop MH, Jarick I, Ehrlich S, Scherag S, Herpertz-Dahlmann B, Zipfel S, Herzog W, de Zwaan M, Burghardt R et al. 2011 Genetic variation of the ghrelin activator gene ghrelin $O$-acyltransferase (GOAT) is associated with anorexia nervosa. Journal of Psychiatric Research 45 706-711. (doi:10.1016/j.jpsychires.2010.10.001)

Nagaya N \& Kangawa K 2003 Ghrelin, a novel growth hormone-releasing peptide, in the treatment of chronic heart failure. Regulatory Peptides 114 71-77. (doi:10.1016/S0167-0115(03)00117-4)

Nagaya N, Kojima M, Uematsu M, Yamagishi M, Hosoda H, Oya H, Hayashi Y \& Kangawa K 2001 Hemodynamic and hormonal effects of human ghrelin in healthy volunteers. American Journal of Physiology. Regulatory, Integrative and Comparative Physiology 280 R1483-R1487.

Nakazato M, Murakami N, Date Y, Kojima M, Matsuo H, Kangawa K \& Matsukura S 2001 A role for ghrelin in the central regulation of feeding. Nature 409 194-198. (doi:10.1038/35051587)

Nanzer AM, Khalaf S, Mozid AM, Fowkes RC, Patel MV, Burrin JM, Grossman AB \& Korbonits M 2004 Ghrelin exerts a proliferative effect on a rat pituitary somatotroph cell line via the mitogen-activated protein kinase pathway. European Journal of Endocrinology 151 233-240. (doi:10.1530/eje.0.1510233)

Nass R, Farhy LS, Liu J, Prudom CE, Johnson ML, Veldhuis P, Pezzoli SS, Oliveri MC, Gaylinn BD, Geysen HM et al. 2008 Evidence for acylghrelin modulation of growth hormone release in the fed state. Journal of Clinical Endocrinology and Metabolism 93 1988-1994. (doi:10.1210/jc.2007-2234)

Nazakato M, Murakami N, Date Y, Kojima M, Matsuo H, Kangawa K \& Matsukura S 2001 A role for ghrelin in the central regulation of feeding. Nature 409 194-198. (doi:10.1038/35051587)

Nishi Y, Yoh J, Hiejima H \& Kojima M 2011 Structures and molecular forms of the ghrelin-family peptides. Peptides 32 2175-2182. (doi:10.1016/ j.peptides.2011.07.024)

Nogueiras R, Pfluger P, Tovar S, Arnold M, Mitchell S, Morris A, Perez-Tilve D, Vazquez MJ, Wiedmer P, Castaneda TR et al. 2007 Effects of obestatin on energy balance and growth hormone secretion in rodents. Endocrinology 148 21-26. (doi:10.1210/en.2006-0915)

Norrelund H, Hansen TK, Orskov H, Hosoda H, Kojima M, Kangawa K, Weeke J, Moller N, Christiansen JS \& Jorgensen JO 2002 Ghrelin immunoreactivity in human plasma is suppressed by somatostatin. Clinical Endocrinology 57 539-546. (doi:10.1046/j.1365-2265.2002. 01649.x)

Ohno T, Mochiki E \& Kuwano H 2010 The roles of motilin and ghrelin in gastrointestinal motility. International Journal of Peptides 2010820794. (doi:10.1155/2010/820794)

Ordway JM, Budiman MA, Korshunova Y, Maloney RK, Bedell JA, Citek RW, Bacher B, Peterson S, Rohlfing T, Hall J et al. 2007 Identification of novel high-frequency DNA methylation changes in breast cancer. PLOS ONE 2 e1314. (doi:10.1371/journal.pone.0001314)

Osawa H 2008 Ghrelin and Helicobacter pylori infection. World Journal of Gastroenterology 14 6327-6333. (doi:10.3748/wjg.14.6327)

Papotti M, Cassoni P, Volante M, Deghenghi R, Muccioli G \& Ghigo E 2001 Ghrelin-producing endocrine tumors of the stomach and intestine. Journal of Clinical Endocrinology and Metabolism 86 5052-5059. (doi:10.1210/jc.86.10.5052)

Patterson M, Murphy KG, le Roux CW, Ghatei MA \& Bloom SR 2005 Characterization of ghrelin-like immunoreactivity in human plasma. Journal of Clinical Endocrinology and Metabolism 90 2205-2211. (doi:10.1210/jc.2004-1641)

Pazos Y, Alvarez CJ, Camina JP, Al-Massadi O, Seoane LM \& Casanueva FF 2009 Role of obestatin on growth hormone secretion: an in vitro approach. Biochemical and Biophysical Research Communications 390 1377-1381. (doi:10.1016/j.bbrc.2009.10.163)

Pecori Giraldi F, Bucciarelli LG, Saccani A, Scacchi M, Pesce S, Losa M \& Cavagnini F 2007 Ghrelin stimulates adrenocorticotrophic hormone (ACTH) secretion by human ACTH-secreting pituitary adenomas in vitro. Journal of Neuroendocrinology 19 208-212. (doi:10.1111/ j.1365-2826.2006.01521.x)

Pettersson I, Muccioli G, Granata R, Deghenghi R, Ghigo E, Ohlsson C \& Isgaard J 2002 Natural (ghrelin) and synthetic (hexarelin) GH secretagogues stimulate H9c2 cardiomyocyte cell proliferation. Journal of Endocrinology 175 201-209. (doi:10.1677/joe.0.1750201)

Proto C, Romualdi D, Cento RM, Spada RS, Di Mento G, Ferri R \& Lanzone A 2006 Plasma levels of neuropeptides in Alzheimer's disease. Gynecological Endocrinology 22 213-218. (doi:10.1080/ 09513590500519385)

Qader SS, Hakanson R, Rehfeld JF, Lundquist I \& Salehi A 2008 Proghrelinderived peptides influence the secretion of insulin, glucagon, pancreatic polypeptide and somatostatin: a study on isolated islets from mouse and rat pancreas. Regulatory Peptides 146 230-237. (doi:10.1016/j.regpep.2007.09.017)

Raghay K, Garcia-Caballero T, Bravo S, Alvarez CV, Gonzalez R, Dieguez C, Beiras A, Fraga M \& Gallego R 2008 Ghrelin localization in the medulla of rat and human adrenal gland and in pheochromocytomas. Histology and Histopathology 23 57-65.

Reichenbach A, Steyn FJ, Sleeman MW \& Andrews ZB 2012 Ghrelin receptor expression and colocalization with anterior pituitary hormones using a GHSR-GFP mouse line. Endocrinology 153 5452-5466. (doi:10.1210/en.2012-1622)

Reimer MK, Pacini G \& Ahren B 2003 Dose-dependent inhibition by ghrelin of insulin secretion in the mouse. Endocrinology 144 916-921. (doi:10.1210/en.2002-220819)

Rigamonti AE, Pincelli AI, Corra B, Viarengo R, Bonomo SM, Galimberti D, Scacchi M, Scarpini E, Cavagnini F \& Muller EE 2002 Plasma ghrelin concentrations in elderly subjects: comparison with anorexic and obese patients. Journal of Endocrinology 175 R1-R5. (doi:10.1677/joe.0.175R001)

Rindi G, Savio A, Torsello A, Zoli M, Locatelli V, Cocchi D, Paolotti D \& Solcia E 2002 Ghrelin expression in gut endocrine growths. Histochemistry and Cell Biology 117 521-525. (doi:10.1007/s00418-002-0416-0) 
Rotondo F, Cusimano M, Scheithauer BW, Rotondo A, Syro LV \& Kovacs K 2011 Ghrelin immunoexpression in pituitary adenomas. Pituitary 14 318-322. (doi:10.1007/s11102-011-0296-1)

Rotondo F, Rotondo A, Scheithauer BW, Cusimano M, Latta E, Syro LV \& Kovacs K 2012 Ghrelin immunoexpression in the human hypophysis. Applied Immunohistochemistry \& Molecular Morphology 20 77-81. (doi:10.1097/PAI.0b013e3182247506)

Rubinfeld H, Hadani M, Taylor JE, Dong JZ, Comstock J, Shen Y, DeOliveira D, Datta R, Culler MD \& Shimon I 2004 Novel ghrelin analogs with improved affinity for the GH secretagogue receptor stimulate GH and prolactin release from human pituitary cells. European Journal of Endocrinology 151 787-795. (doi:10.1530/eje.0.1510787)

Rucinski M, Ziolkowska A, Tyczewska M \& Malendowicz LK 2009 Expression of prepro-ghrelin and related receptor genes in the rat adrenal gland and evidences that ghrelin exerts a potent stimulating effect on corticosterone secretion by cultured rat adrenocortical cells. Peptides 30 1448-1455. (doi:10.1016/j.peptides.2009.04.016)

Sakata I, Yang J, Lee C, Osborne-Lawrence S, Rovinsky S, Elmquist JK \& Zigman J 2009 Co-localization of ghrelin $O$-acyltransferase (GOAT) and ghrelin in gastric mucosal cells. American Journal of Physiology. Endocrinology and Metabolism 297 E134-E141. (doi:10.1152/ajpendo. 90859.2008)

Sato M, Nakahara K, Goto S, Kaiya H, Miyazato M, Date Y, Nakazato M, Kangawa K \& Murakami N 2006 Effects of ghrelin and des-acyl ghrelin on neurogenesis of the rat fetal spinal cord. Biochemical and Biophysical Research Communications 350 598-603. (doi:10.1016/j.bbrc. 2006.09.088)

Sato T, Nakamura Y, Shiimura Y, Ohgusu H, Kangawa K \& Kojima M 2012 Structure, regulation and function of ghrelin. Journal of Biochemistry 151 119-128. (doi:10.1093/jb/mvr134)

Seim I, Herington AC \& Chopin LK 2009 New insights into the molecular complexity of the ghrelin gene locus. Cytokine \& Growth Factor Reviews 20 297-304. (doi:10.1016/j.cytogfr.2009.07.006)

Seim I, Jeffery PL, de Amorim L, Walpole CM, Fung J, Whiteside EJ, Lourie R, Herington AC \& Chopin LK 2013a Ghrelin O-acyltransferase (GOAT) is expressed in prostate cancer tissues and cell lines and expression is differentially regulated in vitro by ghrelin. Reproductive Biology and Endocrinology 11 70. (doi:10.1186/1477-7827-11-70)

Seim I, Lubik AA, Lehman ML, Tomlinson N, Whiteside EJ, Herington AC, Nelson CC \& Chopin LK $2013 b$ Cloning of a novel insulin-regulated ghrelin transcript in prostate cancer. Journal of Molecular Endocrinology 50 179-191. (doi:10.1530/JME-12-0150)

Shibata N, Ohnuma T, Kuerban B, Komatsu M \& Arai H 2011 Genetic association between ghrelin polymorphisms and Alzheimer's disease in a Japanese population. Dementia and Geriatric Cognitive Disorders 32 178-181. (doi:10.1159/000333075)

Siegel R, Naishadham D \& Jemal A 2013 Cancer statistics, 2013. CA: A Cancer Journal for Clinicians 63 11-30. (doi:10.3322/caac.21166)

Spencer SJ, Xu L, Clarke MA, Lemus M, Reichenbach A, Geenen B, Kozicz T \& Andrews ZB 2012 Ghrelin regulates the hypothalamic-pituitaryadrenal axis and restricts anxiety after acute stress. Biological Psychiatry 72 457-465. (doi:10.1016/j.biopsych.2012.03.010)

Stevanovic D, Trajkovic V, Muller-Luhlhoff S, Brandt E, Abplanalp W, Bumke-Vogt C, Liehl B, Wiedmer P, Janjetovic K, Starcevic V et al. 2013 Ghrelin-induced food intake and adiposity depend on central mTORC1/S6K1 signaling. Molecular and Cellular Endocrinology $\mathbf{3 8 1}$ 280-290. (doi:10.1016/j.mce.2013.08.009)

Stoyanova II, le Feber J \& Rutten WL 2013 Ghrelin stimulates synaptic formation in cultured cortical networks in a dose-dependent manner. Regulatory Peptides 186C 43-48. (doi:10.1016/j.regpep.2013.07.004)

Szentirmai E, Kapas L, Sun Y, Smith RG \& Krueger JM 2009 The preproghrelin gene is required for the normal integration of thermoregulation and sleep in mice. PNAS 106 14069-14074. (doi:10.1073/pnas.0903090106)

Tack J, Depoortere I, Bisschops R, Delporte C, Coulie B, Meulemans A, Janssens J \& Peeters T 2006 Gastrointestinal motility: influence of

http://joe.endocrinology-journals.org DOI: 10.1530/JOE-13-0391
() 2014 Society for Endocrinology Printed in Great Britain ghrelin on interdigestive gastrointestinal motility in humans. Gut $\mathbf{5 5}$ 327-333. (doi:10.1136/gut.2004.060426)

Takaya K, Ariyasu H, Kanamoto N, Iwakura H, Yoshimoto A, Harada M, Mori K, Komatsu Y, Usui T, Shimatsu A et al. 2000 Ghrelin strongly stimulates growth hormone release in humans. Journal of Clinical Endocrinology and Metabolism 85 4908-4911. (doi:10.1210/jc.85.12.4908)

Tassone F, Broglio F, Destefanis S, Rovere S, Benso A, Gottero C, Prodam F, Rossetto R, Gauna C, van der Lely AJ et al. 2003 Neuroendocrine and metabolic effects of acute ghrelin administration in human obesity. Journal of Clinical Endocrinology and Metabolism 88 5478-5483. (doi:10.1210/jc.2003-030564)

Taub DD 2008 Novel connections between the neuroendocrine and immune systems: the ghrelin immunoregulatory network. Vitamins and Hormones 77 325-346.

Taub DD, Murphy WJ \& Longo DL 2010 Rejuvenation of the aging thymus: growth hormone-mediated and ghrelin-mediated signaling pathways. Current Opinion in Pharmacology 10 408-424. (doi:10.1016/j.coph.2010. 04.015)

Taylor MS, Ruch TR, Hsiao PY, Hwang Y, Zhang P, Dai L, Huang CR, Berndsen CE, Kim MS, Pandey A et al. 2013 Architectural organization of the metabolic regulatory enzyme ghrelin-O-acyltransferase. Journal of Biological Chemistry 288 32211-32228. (doi:10.1074/ jbc.M113.510313)

Tesauro M, Schinzari F, Caramanti M, Lauro R \& Cardillo C 2010 Cardiovascular and metabolic effects of ghrelin. Current Diabetes Reviews 6 228-235. (doi:10.2174/157339910791658871)

Theodoropoulou A, Metallinos IC, Psyrogiannis A, Vagenakis GA \& Kyriazopoulou V 2012 Ghrelin and leptin secretion in patients with moderate Alzheimer's disease. Journal of Nutrition, Health \& Aging 16 472-477. (doi:10.1007/s12603-012-0058-4)

Thomas GB, Fairhall KM \& Robinson IC 1997 Activation of the hypothalamo-pituitary-adrenal axis by the growth hormone $(\mathrm{GH})$ secretagogue, GH-releasing peptide-6, in rats. Endocrinology 138 1585-1591. (doi:10.1210/en.138.4.1585)

Tokizawa K, Onoue Y, Uchida Y \& Nagashima K 2012 Ghrelin induces timedependent modulation of thermoregulation in the cold. Chronobiology International 29 736-746. (doi:10.3109/07420528.2012.678452)

Tolle V, Zizzari P, Tomasetto C, Rio MC, Epelbaum J \& Bluet-Pajot MT 2001 In vivo and in vitro effects of ghrelin/motilin-related peptide on growth hormone secretion in the rat. Neuroendocrinology 73 54-61. (doi:10.1159/000054620)

Tortorella C, Macchi C, Spinazzi R, Malendowicz LK, Trejter M \& Nussdorfer GG 2003 Ghrelin, an endogenous ligand for the growth hormone-secretagogue receptor, is expressed in the human adrenal cortex. International Journal of Molecular Medicine 12 213-217.

Trudel L, Tomasetto C, Rio MC, Bouin M, Plourde V, Eberling P \& Poitras P $2002 \mathrm{Ghrelin} /$ motilin-related peptide is a potent prokinetic to reverse gastric postoperative ileus in rat. American Journal of Physiology. Gastrointestinal and Liver Physiology 282 G948-G952. (doi:10.1152/ ajpgi.00339.2001)

Tschop M, Smiley DL \& Heiman ML 2000 Ghrelin induces adiposity in rodents. Nature 407 908-913. (doi:10.1038/35038090)

Ueberberg B, Unger N, Sheu SY, Walz MK, Schmid KW, Saeger W, Mann K \& Petersenn S 2008 Differential expression of ghrelin and its receptor (GHS-R1a) in various adrenal tumors and normal adrenal gland. Hormone and Metabolic Research 40 181-188. (doi:10.1055/s-20071004574)

Vestergaard ET, Hansen TK, Gormsen LC, Jakobsen P, Moller N, Christiansen JS \& Jorgensen JO 2007 Constant intravenous ghrelin infusion in healthy young men: clinical pharmacokinetics and metabolic effects. American Journal of Physiology. Endocrinology and Metabolism 292 E1829-E1836. (doi:10.1152/ajpendo.00682.2006)

Vestergaard ET, Djurhuus CB, Gjedsted J, Nielsen S, Moller N, Holst JJ, Jorgensen JO \& Schmitz O 2008 Acute effects of ghrelin administration on glucose and lipid metabolism. Journal of Clinical Endocrinology and Metabolism 93 438-444. (doi:10.1210/jc.2007-2018) 
Vestergaard ET, Krag MB, Poulsen MM, Pedersen SB, Moller N, Jorgensen JO \& Jessen N 2013 Ghrelin- and GH-induced insulin resistance: no association with retinol-binding protein-4. Endocrine Connections 2 96-103. (doi:10.1530/EC-13-0019)

Volante M, Allia E, Gugliotta P, Funaro A, Broglio F, Deghenghi R, Muccioli G, Ghigo E \& Papotti M 2002 Expression of ghrelin and of the GH secretagogue receptor by pancreatic islet cells and related endocrine tumors. Journal of Clinical Endocrinology and Metabolism 87 1300-1308. (doi:10.1210/jc.87.3.1300)

Wagner C, Caplan SR \& Tannenbaum GS 2009 Interactions of ghrelin signaling pathways with the GH neuroendocrine axis: a new and experimentally tested model. Journal of Molecular Endocrinology $\mathbf{4 3}$ 105-119. (doi:10.1677/JME-09-0023)

Wiedmer P, Strasser F, Horvath TL, Blum D, Dimarchi R, Lutz T, Schurmann A, Joost HG, Tschop MH \& Tong J 2011 Ghrelin-induced hypothermia: a physiological basis but no clinical risk. Physiology \& Behavior 105 43-51. (doi:10.1016/j.physbeh.2011.03.027)

Wierup N, Svensson H, Mulder H \& Sundler F 2002 The ghrelin cell: a novel developmentally regulated islet cell in the human pancreas. Regulatory Peptides 107 63-69. (doi:10.1016/S0167-0115(02)00067-8)

Wren AM, Small CJ, Ward HL, Murphy KG, Dakin CL, Taheri S, Kennedy AR, Roberts GH, Morgan DGA, Ghatei MA et al. 2000 The novel hypothalamic peptide ghrelin stimulates food intake and growth hormone secretion. Endocrinology 141 4325-4328. (doi:10.1210/en.141.11.4325)

Wren AM, Seal LJ, Cohen MA, Brynes AE, Frost GS, Murphy KG, Dhillo WS, Ghatei MA \& Bloom SR 2001 Ghrelin enhances appetite and increases food intake in humans. Journal of Clinical Endocrinology and Metabolism 86 5992. (doi:10.1210/jc.86.12.5992)

Wren AM, Small CJ, Fribbens CV, Neary NM, Ward HL, Seal LJ, Ghatei MA \& Bloom SR 2002 The hypothalamic mechanisms of the hypophysiotropic action of ghrelin. Neuroendocrinology 76 316-324. (doi:10.1159/000066629)

Xu L, Gong Y, Wang H, Sun X, Guo F, Gao S \& Gu F 2013 The stimulating effect of ghrelin on gastric motility and firing activity of gastric-distension-sensitive hippocampal neurons and its underlying regulation by the hypothalamus. Experimental Physiology [in press]. (doi:10.1113/expphysiol.2013.074716)

Yamamoto D, Ikeshita N, Daito R, Herningtyas EH, Toda K, Takahashi K, Iida K, Takahashi Y, Kaji H, Chihara K et al. 2007 Neither intravenous nor intracerebroventricular administration of obestatin affects the secretion of GH, PRL, TSH and ACTH in rats. Regulatory Peptides 138 141-144. (doi:10.1016/j.regpep.2006.09.001)

Yamazaki M, Aizawa S, Tanaka T, Sakai T \& Sakata I 2012 Ghrelin increases intracellular $\mathrm{Ca}(2)(+)$ concentration in the various hormone-producing cell types of the rat pituitary gland. Neuroscience Letters 526 29-32. (doi:10.1016/j.neulet.2012.07.063)

Yang H, Dixit VD, Patel K, Vandanmagsar B, Collins G, Sun Y, Smith RG \& Taub DD 2008a Reduction in hypophyseal growth hormone and prolactin expression due to deficiency in ghrelin receptor signaling is associated with Pit-1 suppression: relevance to the immune system. Brain, Behavior, and Immunity 22 1138-1145. (doi:10.1016/j.bbi. 2008.06.003)

Yang J, Brown MS, Liang G, Grishin NV \& Goldstein JL $2008 b$ Identification of the acyltransferase that octanoylates ghrelin, an appetitestimulating peptide hormone. Cell 132 387-396. (doi:10.1016/j.cell. 2008.01.017)

Yang CG, Wang WG, Yan J, Fei J, Wang ZG \& Zheng Q 2013 Gastric motility in ghrelin receptor knockout mice. Molecular Medicine Reports $\mathbf{7}$ 83-88. (doi:10.3892/mmr.2012.1157)

Yeh AH, Jeffery PL, Duncan RP, Herington AC \& Chopin LK 2005 Ghrelin and a novel preproghrelin isoform are highly expressed in prostate cancer and ghrelin activates mitogen-activated protein kinase in prostate cancer. Clinical Cancer Research 11 8295-8303. (doi:10.1158/ 1078-0432.CCR-05-0443)

Yu H, Xu G \& Fan X 2013 The effect of ghrelin on cell proliferation in small intestinal IEC-6 cells. Biomedicine \& Pharmacotherapy 67 235-239. (doi:10.1016/j.biopha.2013.01.007)

Zhang JV, Ren PG, Avsian-Kretchmer O, Luo CW, Rauch R, Klein C \& Hsueh AJ 2005 Obestatin, a peptide encoded by the ghrelin gene, opposes ghrelin's effects on food intake. Science 310 996-999. (doi:10.1126/science.1117255)

Zhang G, Yin X, Qi Y, Pendyala L, Chen J, Hou D \& Tang C 2010 Ghrelin and cardiovascular diseases. Current Cardiology Reviews 6 62-70. (doi:10.2174/157340310790231662)

Zhao CM, Furnes MW, Stenstrom B, Kulseng B \& Chen D 2008 Characterization of obestatin- and ghrelin-producing cells in the gastrointestinal tract and pancreas of rats: an immunohistochemical and electron-microscopic study. Cell Tissue Research 331 575-587. (doi:10.1007/s00441-007-0514-3)

Zheng J, Ariga H, Taniguchi H, Ludwig K \& Takahashi T 2009 Ghrelin regulates gastric phase III-like contractions in freely moving conscious mice. Neurogastroenterology and Motility 21 78-84. (doi:10.1111/ j.1365-2982.2008.01179.x)

Zizzari P, Longchamps R, Epelbaum J \& Bluet-Pajot MT 2007 Obestatin partially affects ghrelin stimulation of food intake and growth hormone secretion in rodents. Endocrinology 148 1648-1653. (doi:10.1210/ en.2006-1231)

Received in final form 29 October 2013

Accepted 5 November 2013

Accepted Preprint published online 5 November 2013
(C) 2014 Society for Endocrinology Printed in Great Britain
Published by Bioscientifica Ltd. 